\title{
نقد النقد عند عبد الله عبد الجبار
}

\author{
ياسر بن سليمان شوشو \\ أستاذ البلاغة والنقد الأدبي المشارك- قسم البلاغة والنقد \\ كلية اللغة العربية- جامعة أم القرى- المملكة العربية السعودية المالية \\ ysshosho@uqu.edu.sa
}


المجلة الدولية للدراسـات اللغوية والأدبية العربية

International Journal for Arabic Linguistics and Literature Studies (JALLS)

www.refaad.com

Journal Homepage: https://www.refaad.com/views/JALS/home.aspx ISSN: 2663-5860(Online) 2663-5852(Print)

\title{
نقـل النقلد عنـل عبـل الله عبـل الجبـار
}

\author{
ياسر بن سليمان شوشو

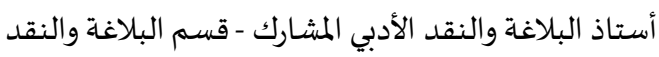

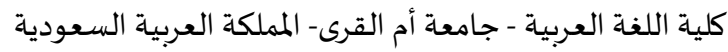 \\ ysshosho@uqu.edu.sa
}

DOI: https://doi.org/10.31559/JALLS2021.3.1.3 2021/4/30 2021/3/20 مراجعة البحث: 2021/4/15 قبول البحث البحث: 2015

الملتخص:

قامت هذه الدراسة على إبراز جانبٍ مهم من جوانب الدراسات النقدية المعاصرة، هو جانب (نقد النقد). ولعل تاريخ النقد

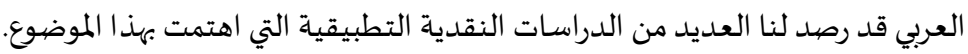

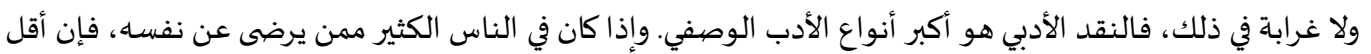

القليل منهم من يرضى عن غيره. وعدم الرضا عن الغير في مجال الرأي نقداً .

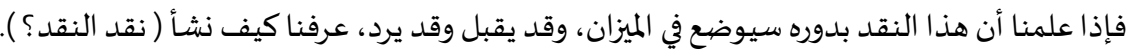

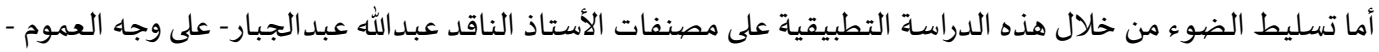

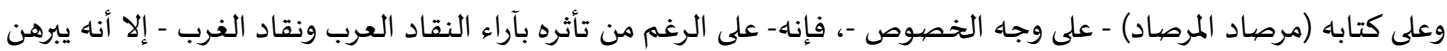

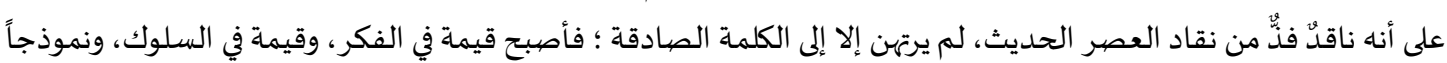

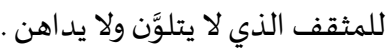
الكلمات المفتاحية: النقد؛ نقد النقد؛ النقد الأدبي؛ عبد الله عبد الجبار ؛ المرصهاد؛ مرصهاد المرصاد.

المقدمة:

لعل من البدهيات التي لا تقبل، الجدل أن بواكير الحركة النقدية في المملكة العربية السعودية كانت تمثّل جزءاً من الحركة

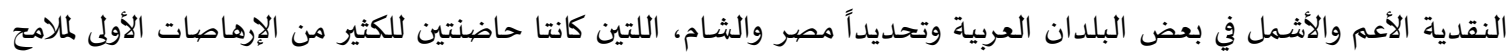
النقد الأدبي في أدبنا العربي الحديث؛ والمتمثلة في ظهور بعض المُ المؤلفات التي استطاعت أن تسلط الضوء عليها من خلال ما أحدثته من

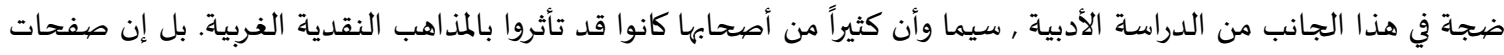

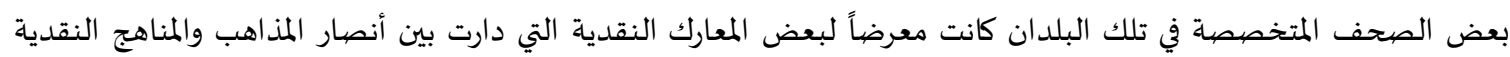

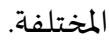

و" نقد النقد" المقصود في هذه الدراسة نعني باء الكتب أو المقالات التي ألفها أصحابها في تفنيد آراء نقدية وردت في كتب أو مقالات نقدية أخرى . ولا شك أن " نقد النقد " ههذا المفهوم يعدّ منهجاً معروفاً في تاريخ نقدنا العربي، وإن لم يسمّ بهذه التسمية إ، نجده عند الآمدي في موازنته حين رد على منتقدي شعر أبي تمام وشعر البحتري، ونجده أيضاً في وساطة القاضي الجرجاني التي بنيت أساساً على هذه 
أما الناقد الذي حظيت به دراستنا هذه لتكون آراؤه النقدية- التي وردت في بعض ما خلّفهه من تراث أدبي ونقدي ضخم- مجالاً للقراءة والتحليل والتوجيه المبني على أسس علمية فهو الأستاذ عبدالله عبد الجبار، أحد أبرز رواد الحركة النقدية التنويرية في بلادنا.

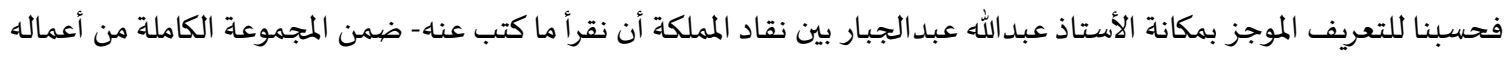

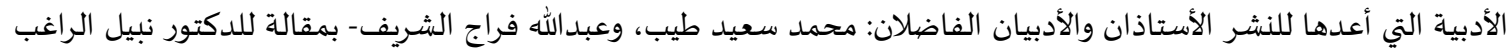

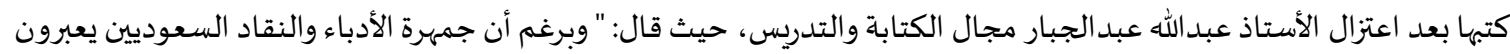

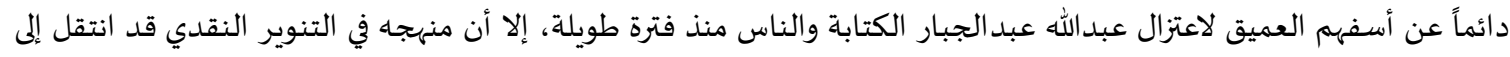

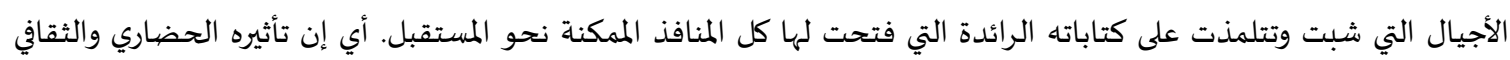

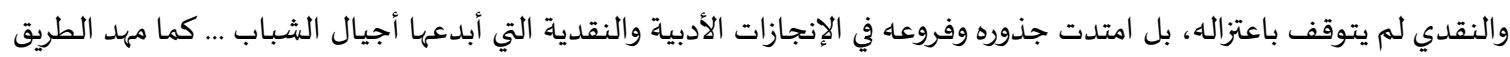

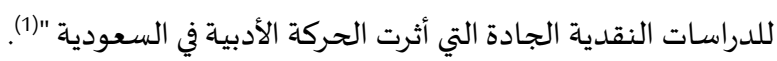

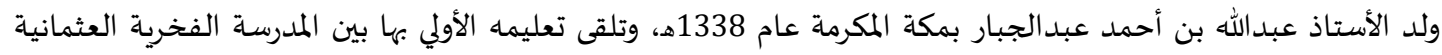
ومدرسة الفلاح، ثم ابتعث إلى مصر ليلتحق بكلية دار العلوم التي تخرج فيها في عام 1359هـ، وعمل مدرساً في مدرسة تحضير الحير البعثات،

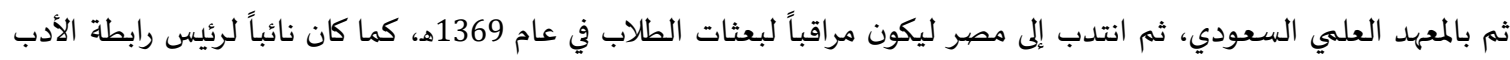
الحديث بالقاهرة.

وقد درَّس الأستاذ عبدالله عبدالجبار اللغة العربية والأدب بلندن، ثم عاد إلى جدة ليعمل مستشاراً بجامعة الملك عبدالعزيز، فمستشاراً لشركة تهامة. لله مجموعة من المؤلفات في النقد والمسرح والقصة والمقالة، إلى جانب المقدمات التي كتبها - رحماه اللهـ لبعض المؤلفات الأدبية .

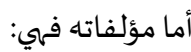
1. التيارات الأدبية في قلب الجزيرة العربية، بقسمياه ( الشعر والنثر).

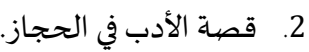
3. ت مرصاد المرصياد. 4. الغزو الفكري في العالم العربي. 5. 6. العم سحتوت (قصة ). 7. 8. الشياطين الخرس ( مسرحية ) (2).

ولأن قامة الأستاذ عبدالله عبدالجبار في مجال الدرسئ الدرس الأدبي -ومن خلال ما أنجزه فياء من نتاج متنوع - أعلى من أن تمكّن

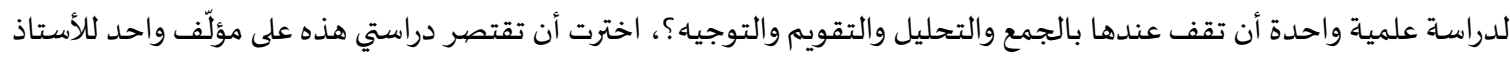

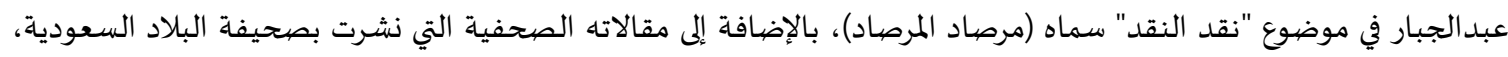
والتي كانت تعدّ نقداً لآراء نقدية كتبت حول قضية الشعر الجديد، أو ما سماه الأستاذ عبدالجبار بـ الشعر الحر ) ."إن مكانة الأستاذ الهاذ عبدالله عبدالجبار تستوجب على النقاد في بلادنا الالتفات إلهها، وإلى عقد الندوات النقدية الرائدة، وتقييمها، ومن ثم دراستها ومحاولة تفكيك خطابه الأدبي، وإلى عقد الندوات النقدية للدخول إلى هذه التجربة بوصفها تجربة رائدة، علينا أن نستشرف من

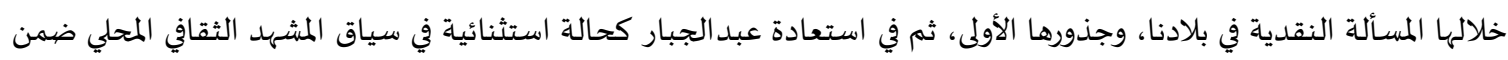

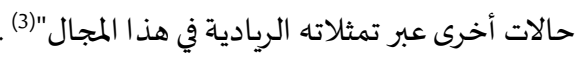

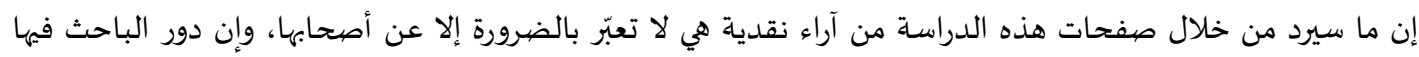

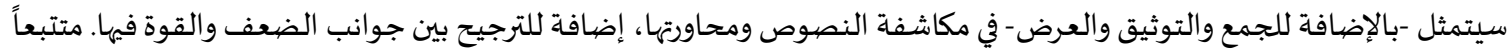

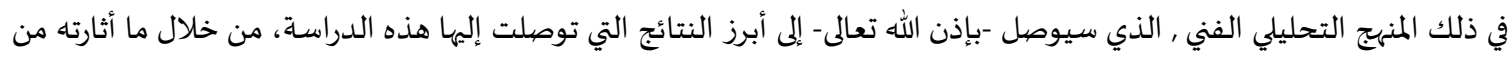
قضايا. والله أسأل أن يلهمنا التوفيق والسـداد في القول والعمل إنه سميعٌ مجيب .

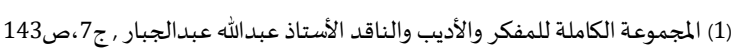

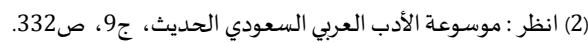

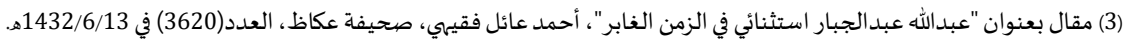




\section{نقد النقد في كتاب (مرصاد المرصهاد):}

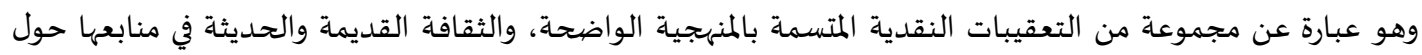

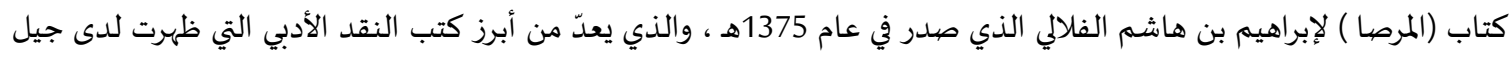

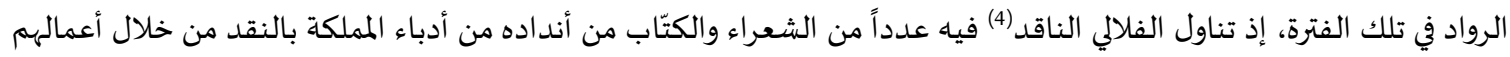

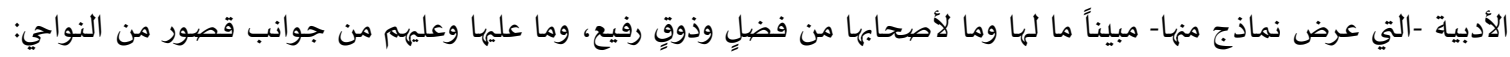
اللغوية أو العروضية أو البلاغية أو التصويرية أو الفنية.

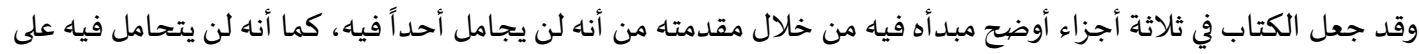

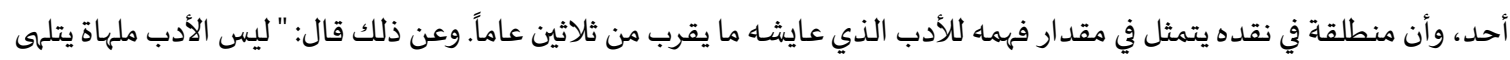

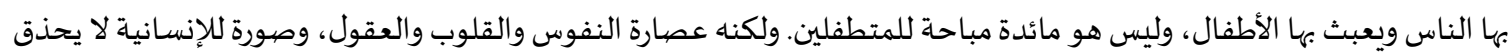

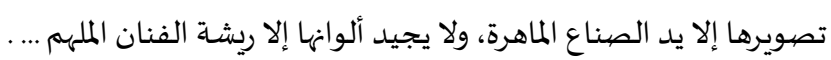

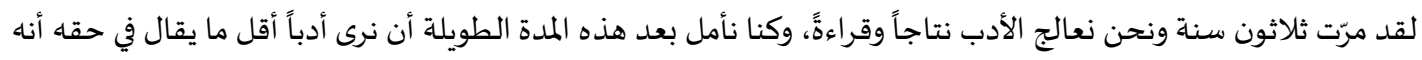

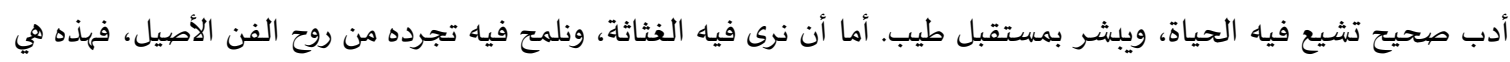

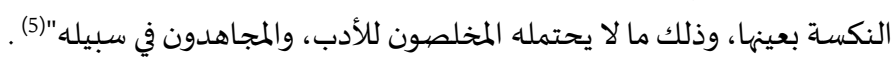

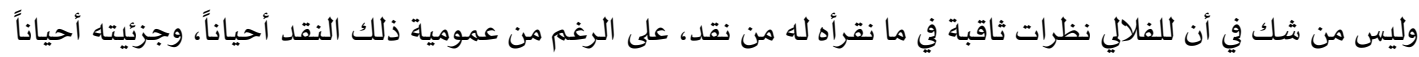

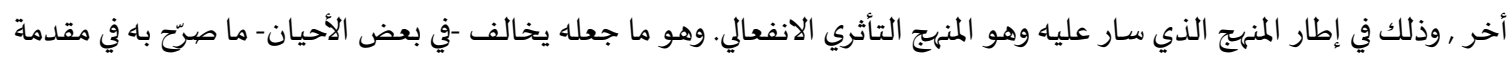

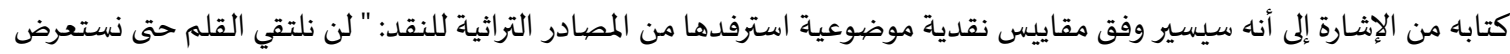

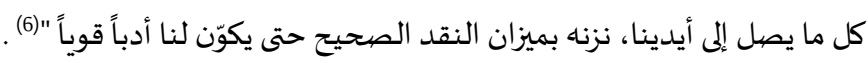

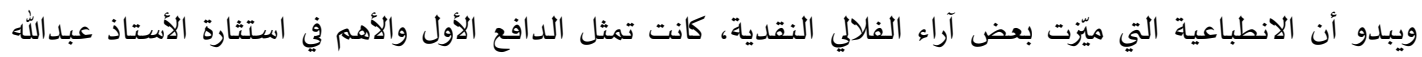

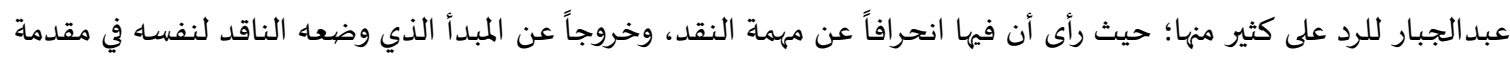

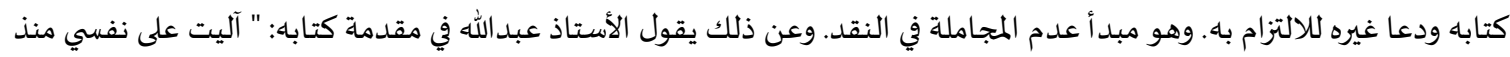

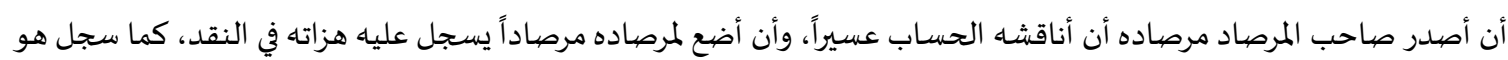

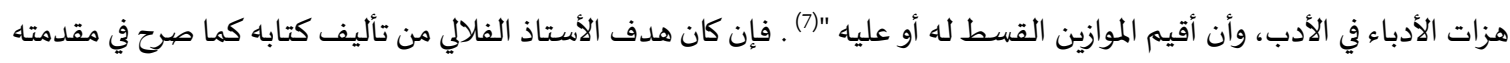

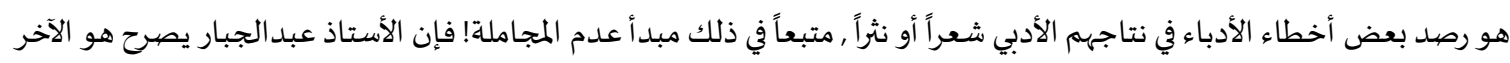

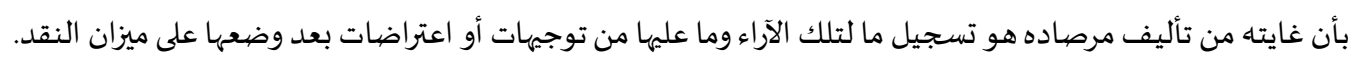

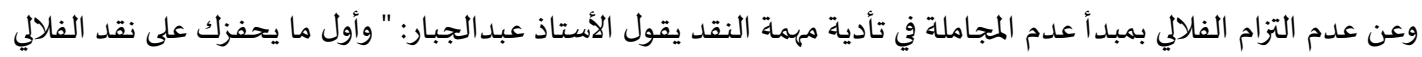

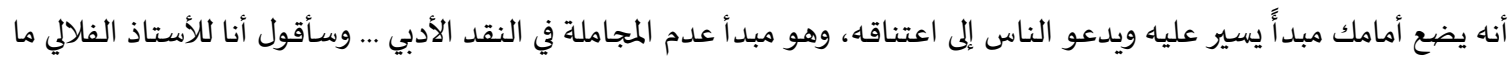

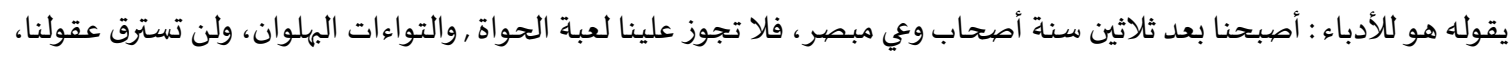

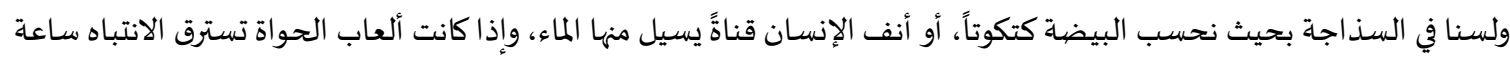

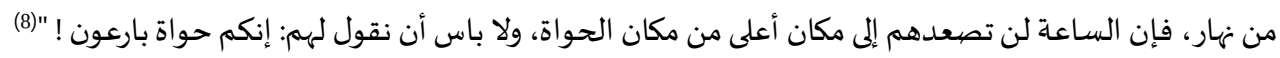

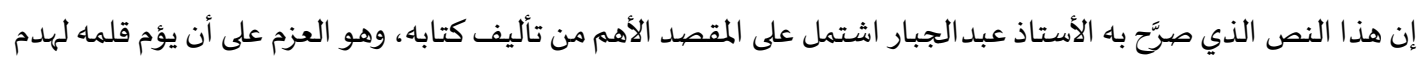

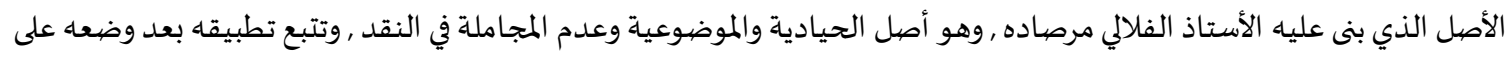

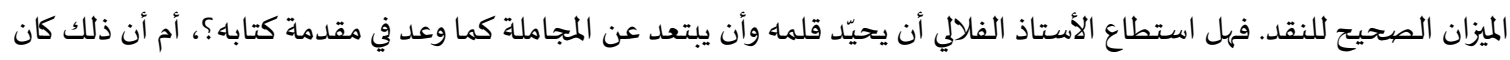

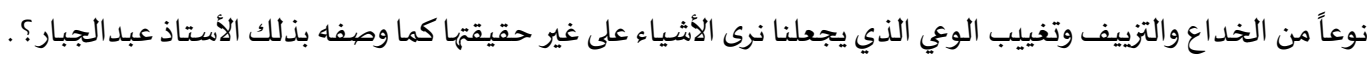

(4) كما أنه شاعر وقاص وكاتب قديم، له عدد من المؤلفات في الشعر والقصة والتراجم والدراسات الإسلامية والاجتماعية، انظر ترجمته بقلم ابنه أسامة في مقدمة كتابه (

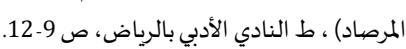

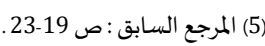

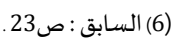

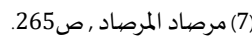

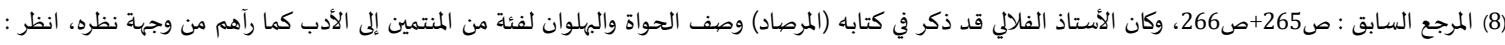
ص101+صالمع السابق. : 
الوقفة الأولى: اعتراضيات بسبب سوء الاختيار:

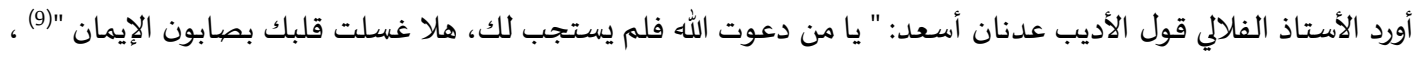

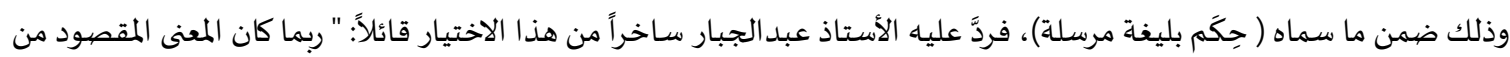

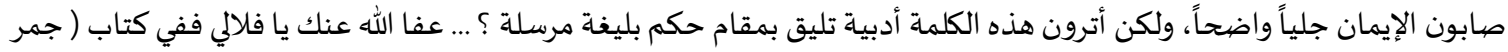

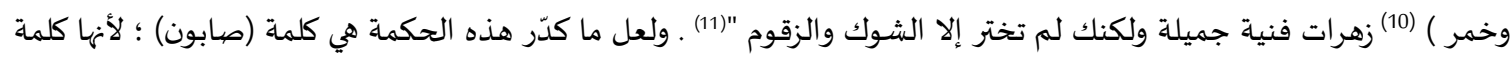

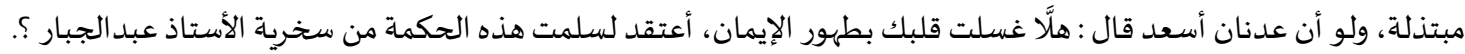

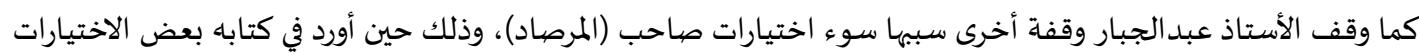

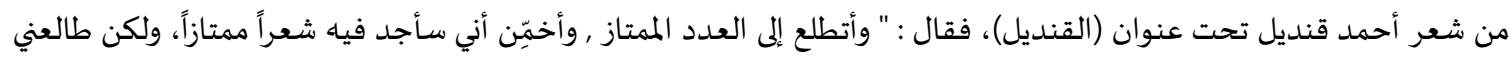

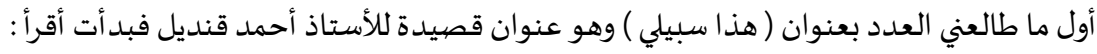
صناعتي في الورى الكلام، به أحيا فقيراً، وحرفتي الأدب أسبدأ

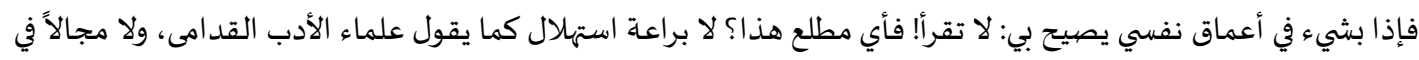

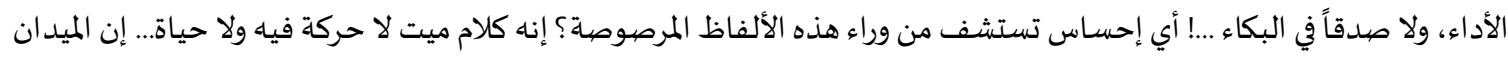

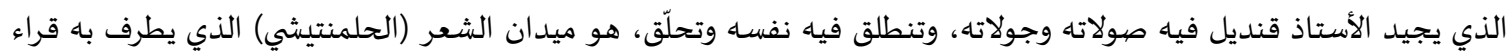

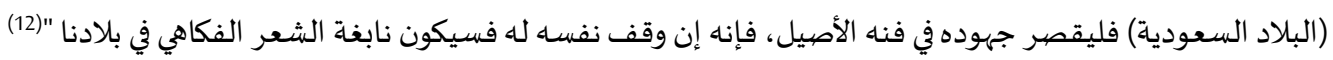

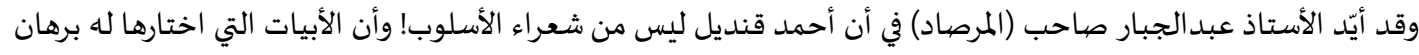

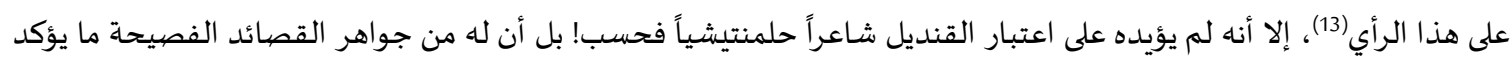

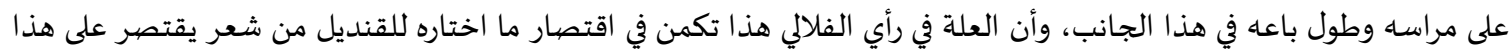

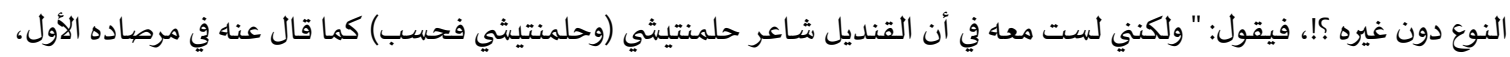

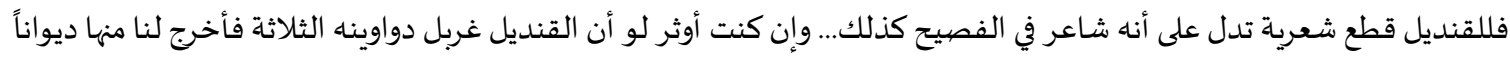

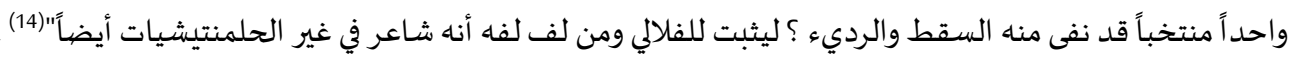

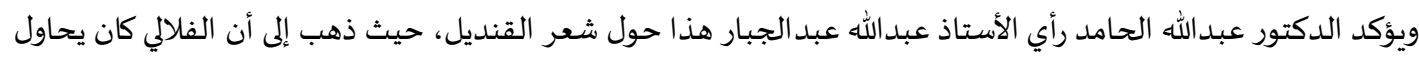

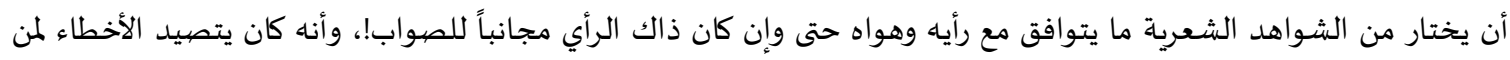

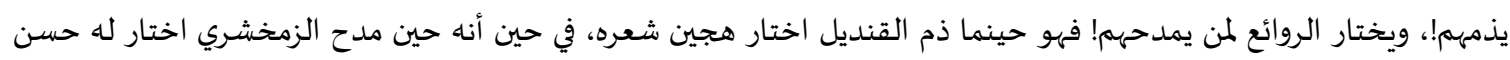

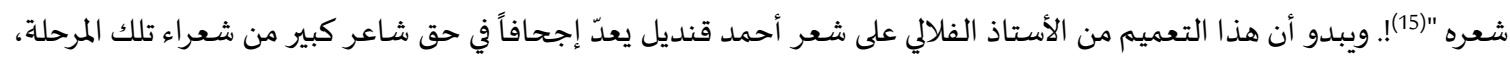

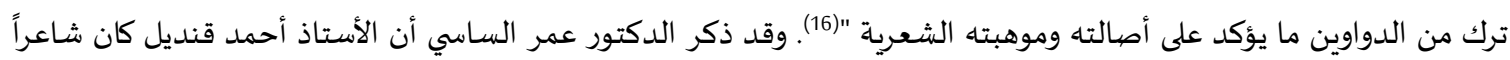

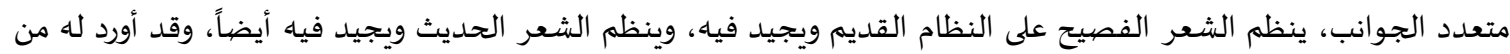

قصائده العمودية الفصيحة قصيدة بعنوان (البلبل)، وهي من الشعر الجيد يقول في مطلعها:
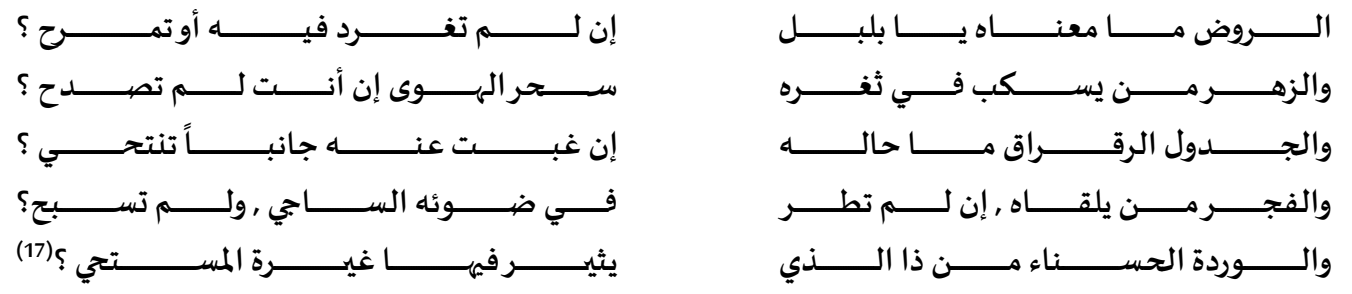

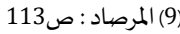

(10) وهو كتاب للأستاذ عدنان أسعد، جمع فيه عدداً من المختارات الأدبية التي اعتمد فيها على ذوقه الأدبي.

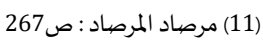

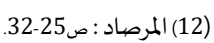

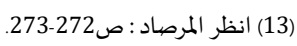

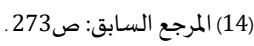

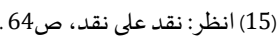

(16) من دواوين الشاعر أحمد قنديل المطبوعة : (الأصداء) )، (الأبراج)، (الأغاريد).

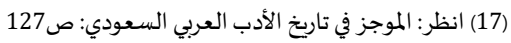


وللأستاذ أحمد قنديل ملحمة تاريخية وطنية شعرية طويلة، تكونت من سبعة أقسام سجل فيها أهم الأحداث التاريخية

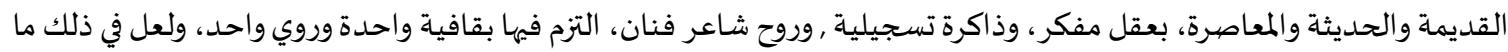

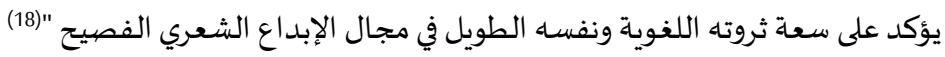
وإن كان سوء اختيار النص الشعري الذي أورده الأستاذ الفلالي للقنديل هو ما دفعها إلى عدم الحيادياة في تعميم حكماه على شعر الشاعر، فإننا نرى الفلالي نفسه قد عاب على من لا يجيد الاختيار الشعري الذي ينشر للقراء والنقاد، وأن عدم الدقة في

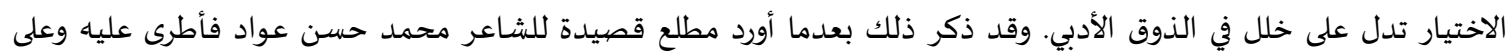

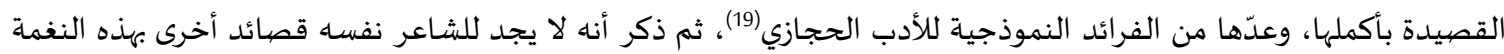
الساحرة التي وجدها في هذه القصيدة؟! وتساءل عن نشر مثل تلك القصائد التي لا ترقى إلى النغمة الساحرة في كتاب " شعراء الحجاز

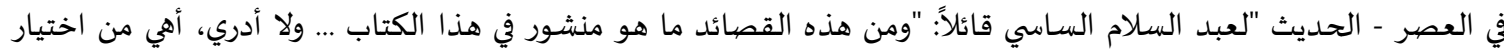
السـاسي؟ أم من اختيار الشاعر نفسـه ؟ فإن كانت من اختيار الشاعر فما أنصف نفساه، ويعد اختياره هذا ظلماً لشـاعريته، وإجحافاً بها ... وهو الذي ترك بهذا الاختيار مجالاً لقلم الناقد. وإن كانت من اختيار الساسي فقد دلل لنا الساسي بهذا الاختيار على أن ذوقها

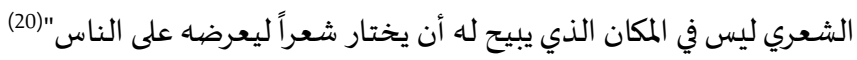
أما ثالث وقفاتنا مع اختيارات صاحب ( المرصاد) التي ردّها عليه الأستاذ عبدالجباديار، فهي وقفتها مع محمد سرور صبان -وقد

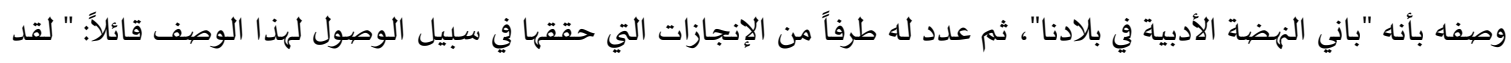

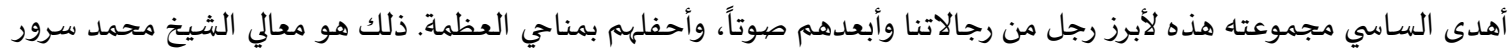

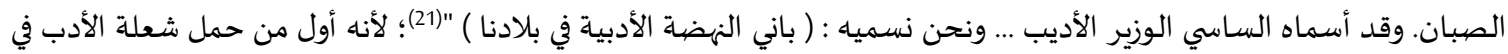

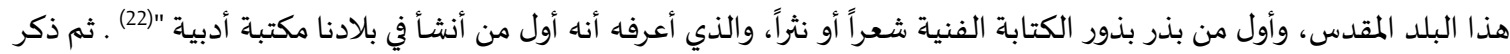

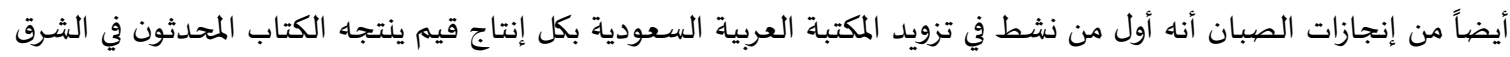

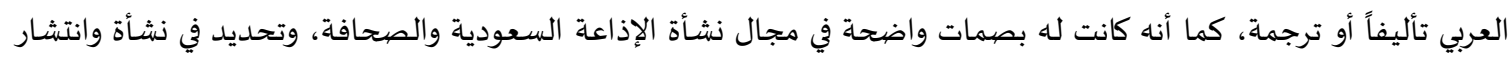

صحيفة البلاد السعودية .. (23).

وعن موقفة الأستاذ عبدالجبار مع الفلالي يقول: " وعندما انتقل الأستاذ الفلالي إلى أدب الشيخ محمد سرور الصببان خيّل

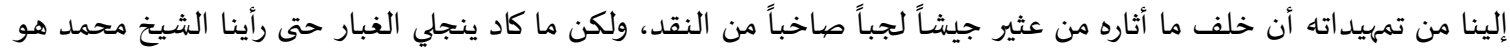

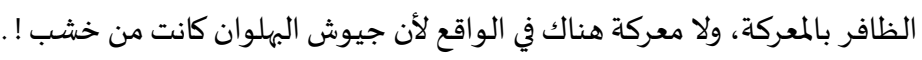

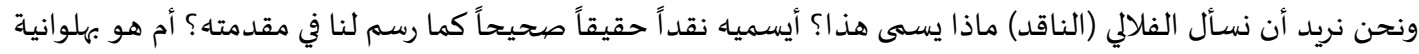

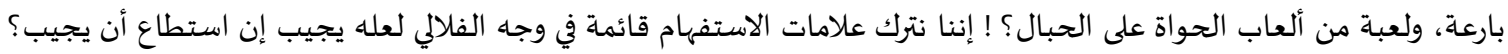
ذلك أننا لم نر في نقده لهذه الشخصية إلا مديحاً متصلاً تتخللها نقاط بسيطة مردودة "(24) . ويبدو أن تحامل الأستاذ عبدالجبار في رده مبالغة الفلالي في الإطراء على الشيخ محمد الصببان كان سبباه اعتبار ذلك الإطراء

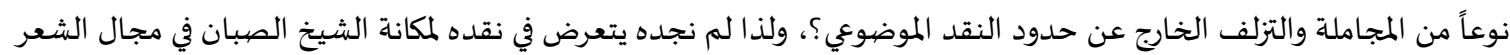
والأدب، وإنما اقتصره على مبالغة الفلالي في الإطراء!. إن ريادة الشيخ الصبان في مجال الأدب إنما قامت أساساً على دعمه شعراء وأدباء الرعيل الأول من معاصيريها , وذلك بحكم

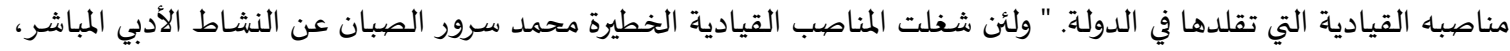

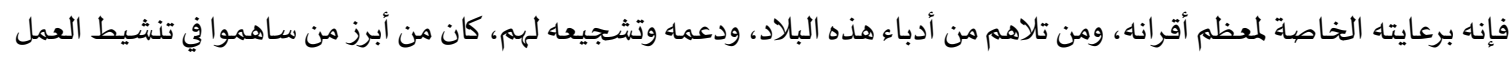

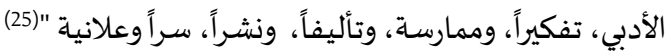

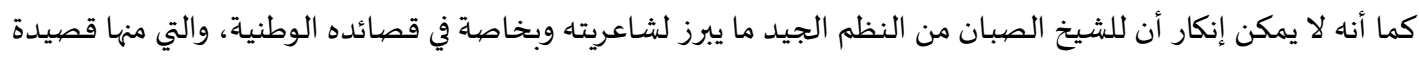

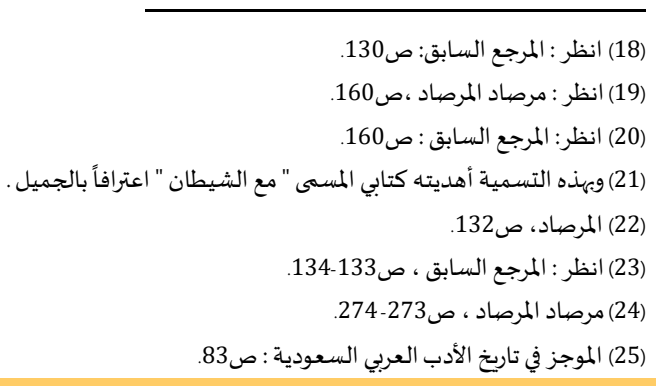


بعنوان (عاطفة النفس)، يقول في مطلعها :

جلّ الأسى وتتابعت زفر اتي ودنا المشيب فقلت حان مماتي
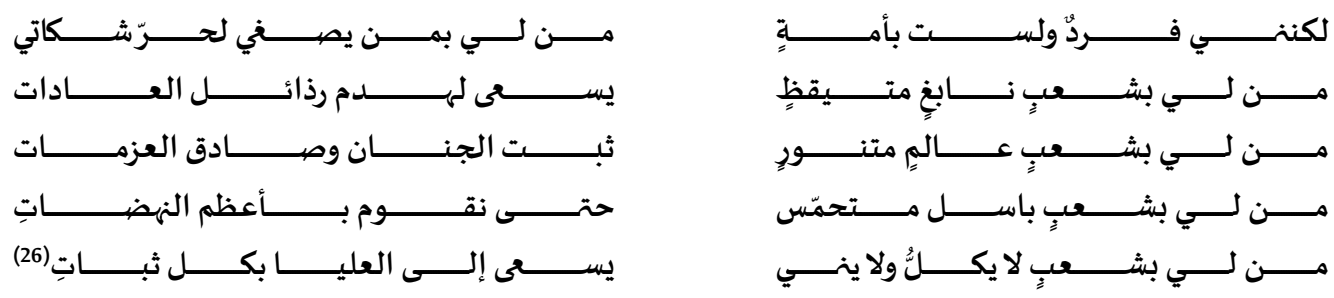

فهذه من القصائد الوطنية التي تؤكد على أن قائلها يحمل همّ أمته , ويستهض همم أهلها، ويوقظ نبوغهه، وهذا ما كان متلائماً جداً مع طبيعة المرحلة التاريخية التي عاشها الشيخ الصبان. كما أن له قصيدة أخرى سماها (يا ليل) .. ناجى فهها الليل بروح
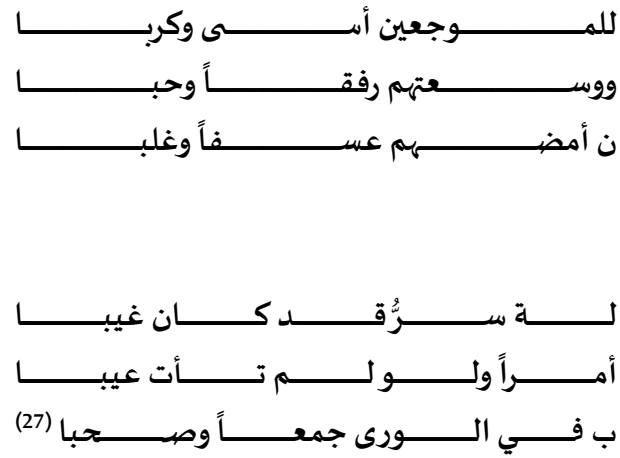

حريصة على النهوض بعزائم أمتاه ووطنها، يقول في مطلعها :

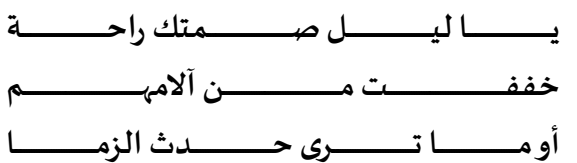

ويمضي في قصيدتاه حتى يصل إلى آخر مقاطعها، فيقول :

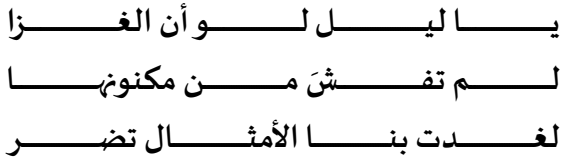

فلا يزال الشاعر مع أباء وطنه المكدودين , وكأنه معهم يلفهم الليل الذي يجدون فياه متنفساً وراحة ... ، على الرغم من أن

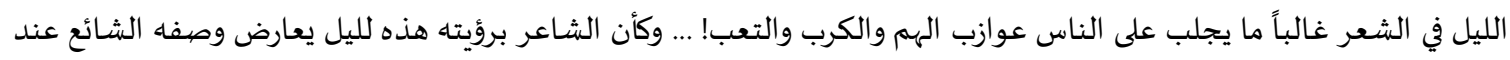

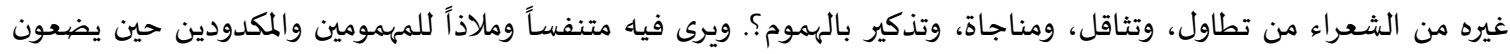

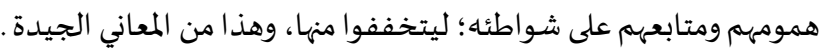
وكان الدكتور عبدالله الحامد قد اعترض على مبالغة الفلالي في الإطراء على الشيخ الصبانه، وعدّه إطراء يهدف إلى إلى إبراز مكانته الشعرية بين معاصريه. وعن ذلك قول: " لقد رفع من شأن شعر عبدالله الخطيب ومحمد سرور الصبان، ولم يكونا إلا من شعراء إنياء

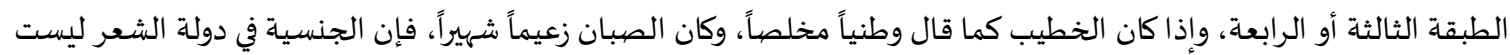

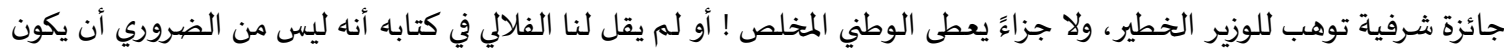
عمالقة الوظائف عمالقة في الأدب "(28). ولعله كان من الواضح أن الأستاذ الفلالي لم يجعل الصبان في مقدمة شعراء تلك المرحلة، بل إن هدفه الذي يفهم من كلامها

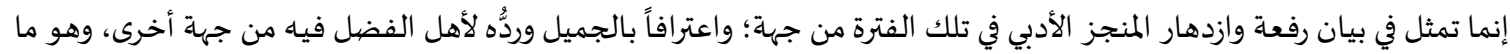

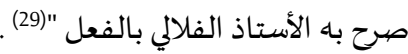
وبنظرة سربعة على اختبارات صاحب (المرصاد) لشخصيات كتابه!، وما أوردها من نماذج لأدبهم!، نلحظ أن الكتاب لم يعتمد

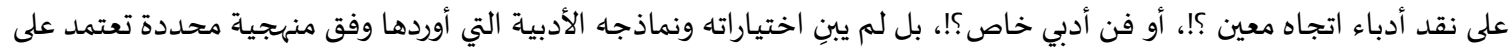

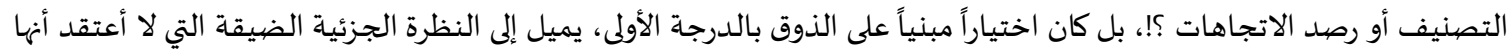
كانت كافية لإصدار أحكام نقدية! .

(26) انظر : شعراء الحجاز في العصر الحديث , ص27 (25:24.

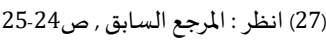

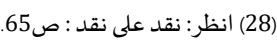
(29) انظر : المرصاد : صانئ. 
انظر إلى تعليقه على ما نشر من شعر محمد سعيد العامودي، حين قال: " إننا نأسف على هذه الشـاعرية ذات الأحلام الذهبية

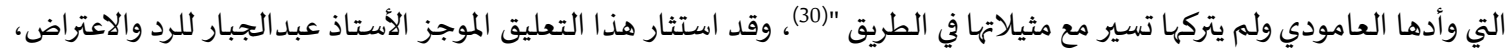

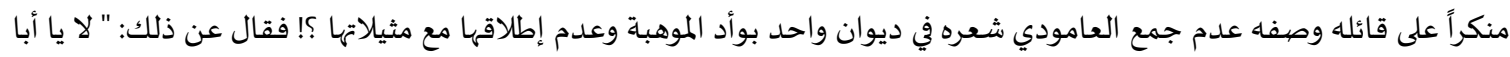

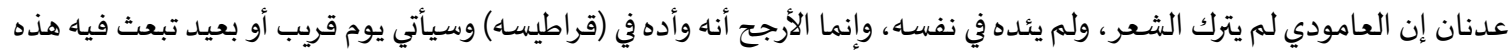

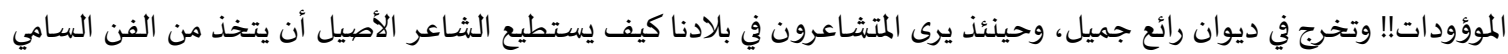

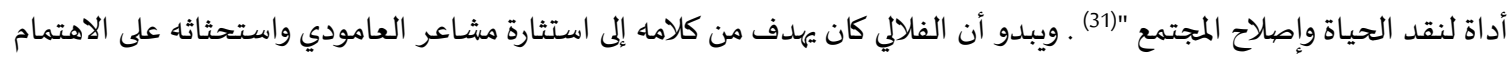

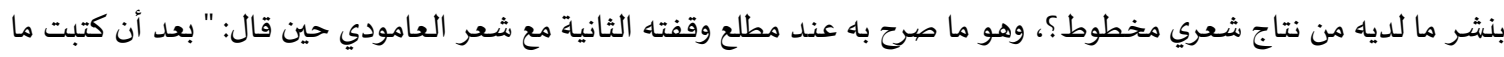

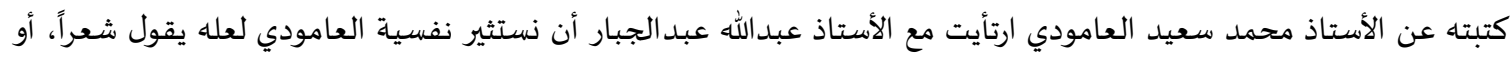

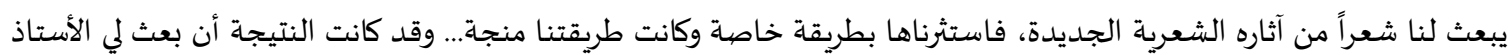

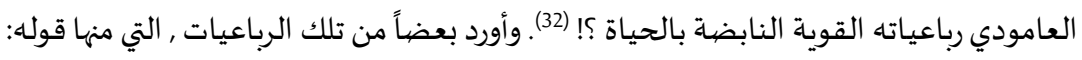
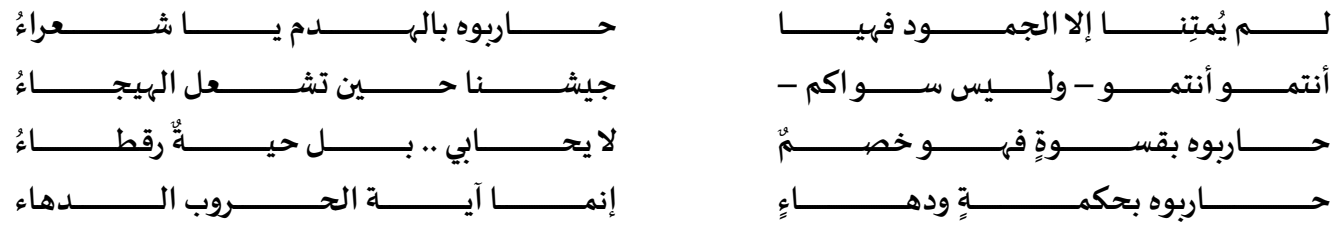

ثم علّق على هذه الأبيات بقوله: " هذه الرباعيات يا قارئي العزيز من الرباعيات التي بعث إليّ بها الأستاذ العامودي بعد الحيلة

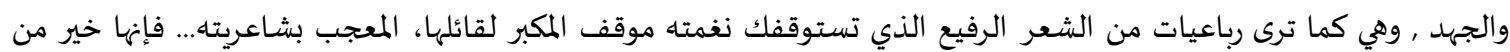
المعلقات المشهورات" ؟!(33) . إنّ من البيّن لا يخفى أن صاحب (المرصياد) من خلال تعليقه هذا قد ناقض تمات تماماً ما انتهجها لنفسه في مقدمة كتابه من نهج

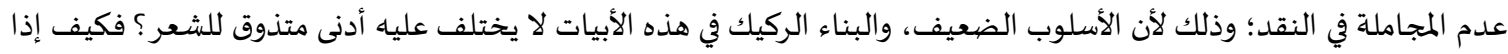
عُدّت أفضل من المعلقات المشهورات ؟(34). فلعل العامودي كان محقاً في أبائه نشر مثل هذه الرباعيات؛ حرصاً منه على ستر الرديء من شعره , ولكن الفلالي - سامحها الله - أبى إلا أن يخرجاه من سلة المهملات ؟إن.

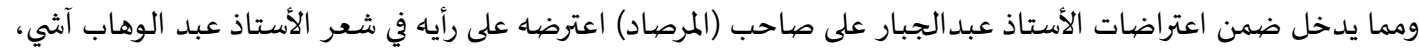

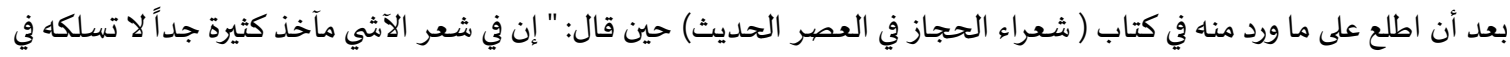

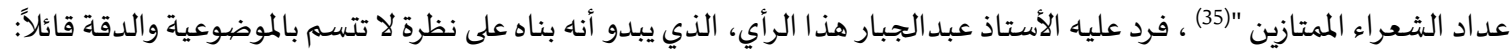

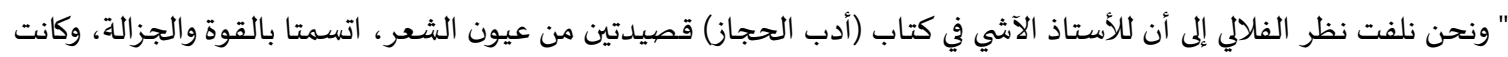

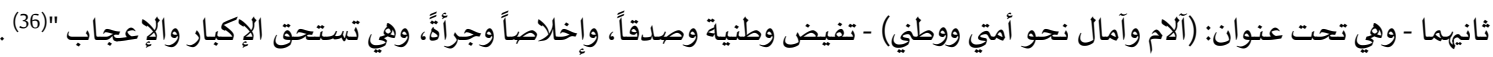

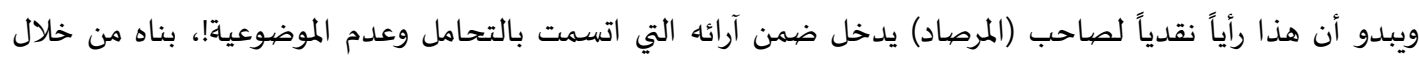

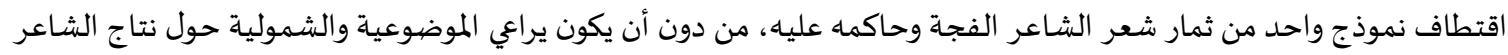

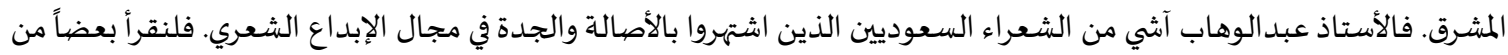

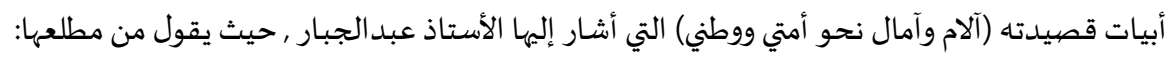

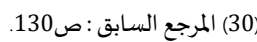

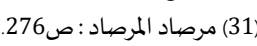

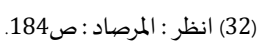

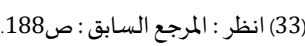

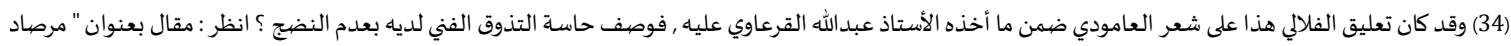

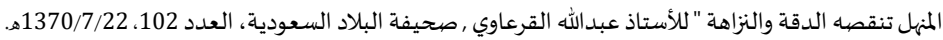

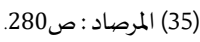

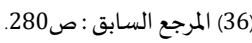



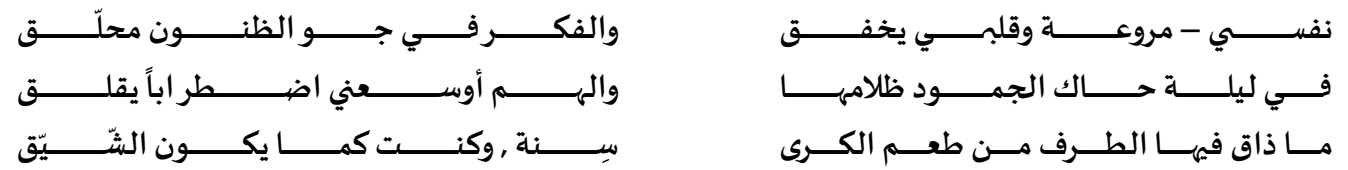

ثم يختم الشـاعر تلك القصيدة الرائعة المتسمة بمشاعر الصيدق والإخلاص والجرأة قائلاً(37):

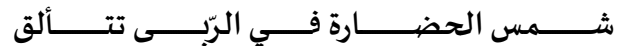

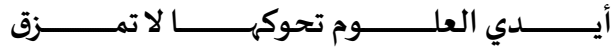

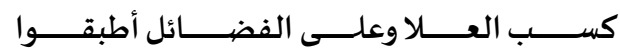

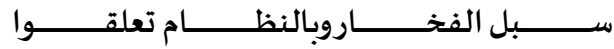

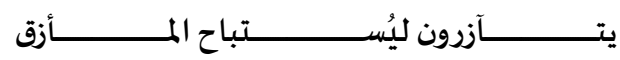

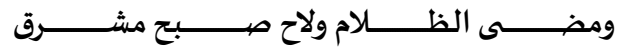

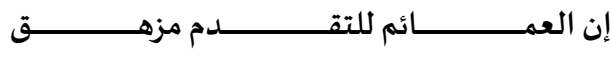

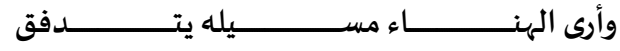

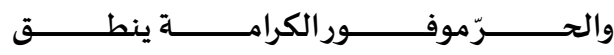

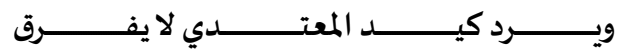

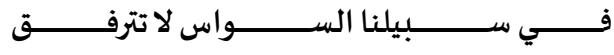

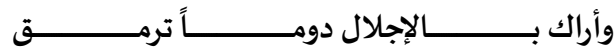

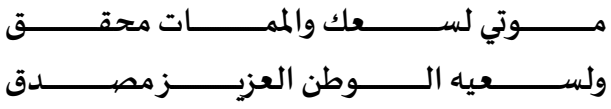

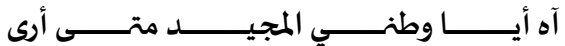

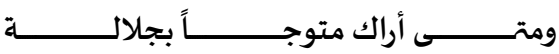

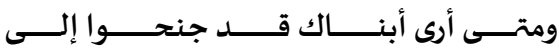

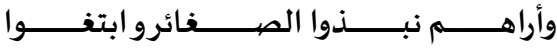

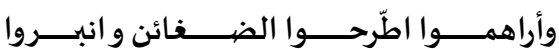

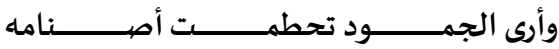

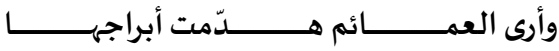

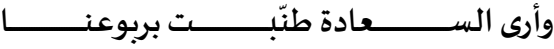

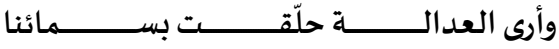

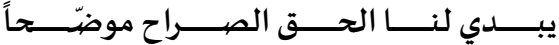

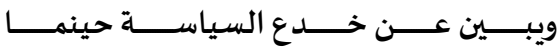

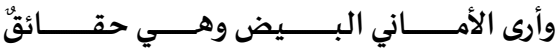

$* * *$

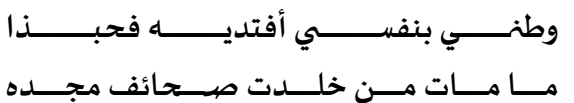

إن هذه القصيدة التي حاول الشاعر أن يجدو فيها وبها قومه ؛ لينتقلوا من حال إلى حال، لتؤكد على أنه شاعر يحمل هم قومه ... فكان له ما أراد !، فقد استطاعت كل كلمة من كلماتها أن تنبض بالحياة ولسان حالها يردد ما تتوق إليه نفس الشاعر ؟! فلو رجعنا

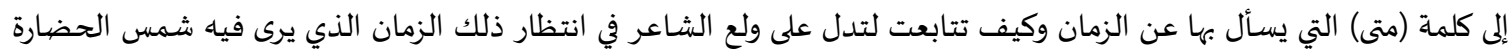
تتألق في وطنه، وفجر العلوم يتجلى فيه ويشرق . ثم تحل محل مكانها كلمة (أرى) وكيف تتشبث هذه الكلمة وتتلاحق لأنها مثلّ حلم

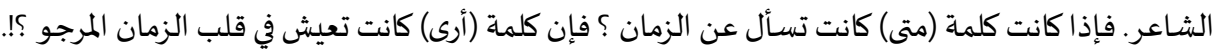
إن هذه القصيدة بكل ما اشتملت عليه من ألفاظ ومعانٍ جليلة وجميلة، لتذكرنا بنغم الشعراء الكبار الذين احتلوا أماكن

مرموقة في التاريخ المشرق للشعر العربي! من أمثال شعر أبي الطيب المتنبي حين قال : ماندان

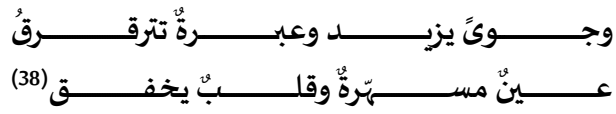

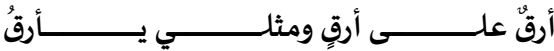

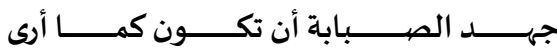

إن أدب ( الاختيار) في تراثنا العربي له قواعده وأصوله التي بني عليها , وألفت المؤلفات المشهورة فيه قديماً وحديثاً، غير أن

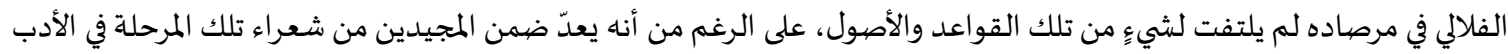

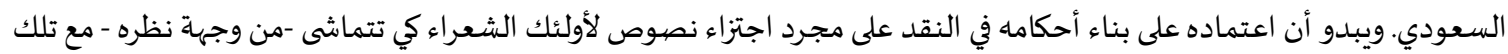
الأحكام قد أوقعه في الإسراف!، سواء كان إسرافاً في المدح لمن اختار لهم الجيد من شعرهم، أو إسرافاً لمن أوقعهم في اختيار الرهاء الرديء

مناه لهم وفق مزاجية لا مبرر لها .

ولهذا يرجح الدكتور الحامد أن بعض ما لأخذ على على الفلالي في مرصاده يرجع إلى كونه ناقداً انفعالياً تأثيرياً، أو ناقداً مستعجلاً ذا

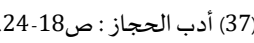

(38) انظر : شرح ديوان المتنبي : ج1 إدجاز : ص332) 
نظرة جزئية، اكتفى في أغلب نقده بقصائد وجدها منشورة في عدد ممتاز من أعداد صحيفة البلاد , بلا مناهج! وعلى عجل ! وباجتزاء!. حيث رأى أنه حاسب تسعة شعراء على قصائد نشرت في عدد واحد من أعداد الصحيفة، ولم يلتفت إلى نتاجهم الغزير الذي يبدو أنه لم يطلع عليه "(39)

الوقفة الثانية: اعتراضـات حول مكونات الشعر: الشات

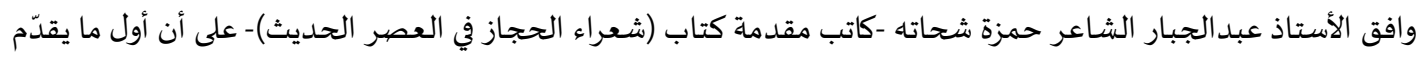

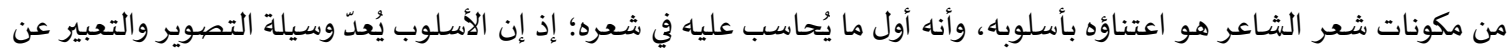

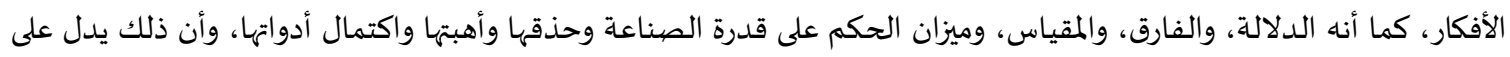
أهميتـه في بلاغة الشعراء ! (40). وسواء كان هذا الرأي قديماً معروفاً لدى نقاد العرب وعلماء إعجاز ؟! أو حديثاً قد أشار إليه النقاد المحدثين؟ فإنهاء يعدّ رأياً

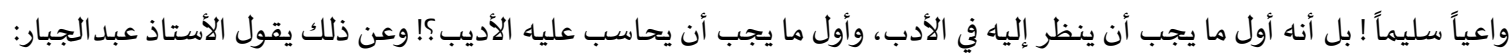

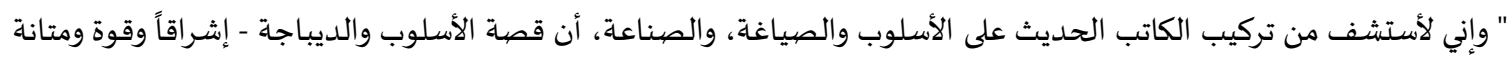
تركيب- هي ما يجب أن نحاسب عليه شعراءنا أولاً، ثم بعد ذلك نحاسبهم على الخيال والعاطفة والمعاني وبقية العناصر المقومة للشعر "(41).

وكان الأستاذ الفلالي قد أشار في حديثه عن مقدمة كتاب (شعراء الحجاز في العصر- الحديث) إلى ضرورة المزاوجة بين

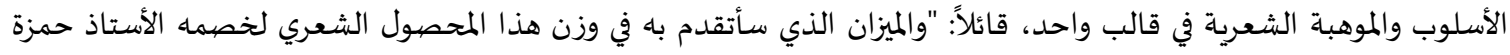

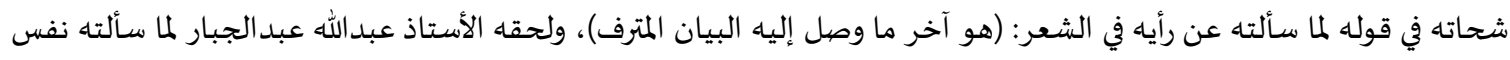

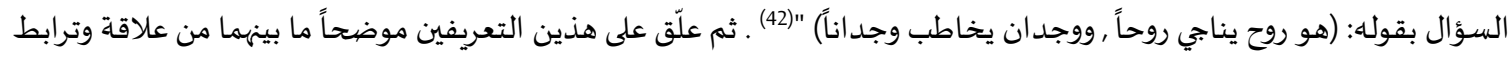

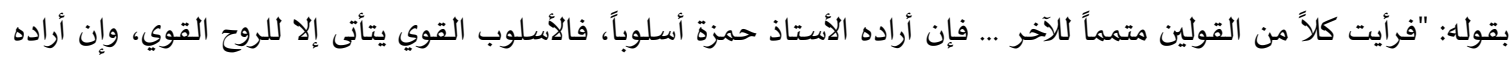

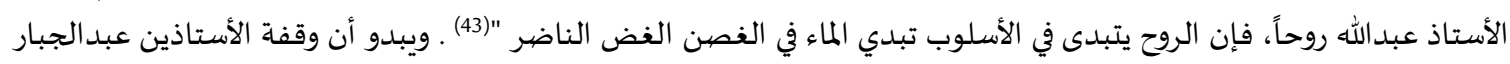
والفلالي مع أهمية الأسلوب في النص الأدبي لم تكن وقفة تعارض واختلاف، وإنـان إنما كانت وقفة توافق وتأييد!؛ كيف أشبع نقاد الأدب في

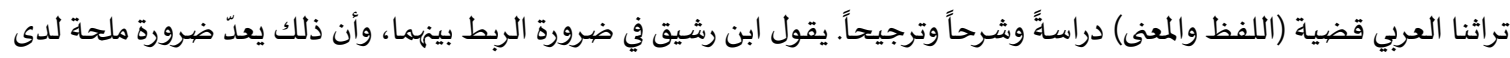

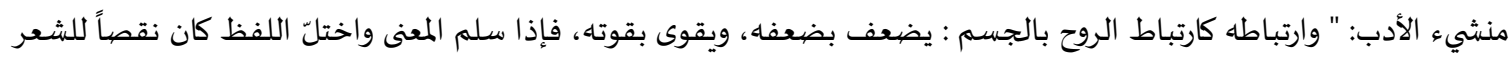
وهجنة عليه... وكذلك إن ضعف المعنى واختلّ بعضيه كان للفظ من ذلك أوفر حظ "(44) .

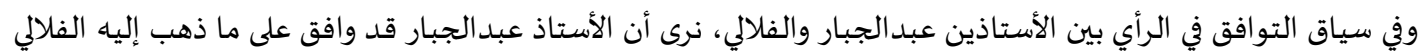

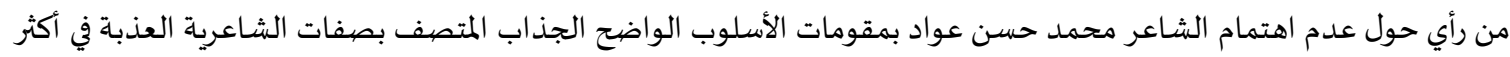

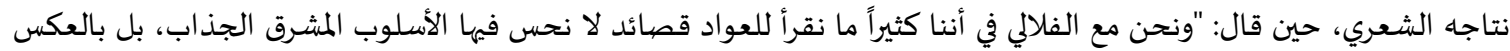

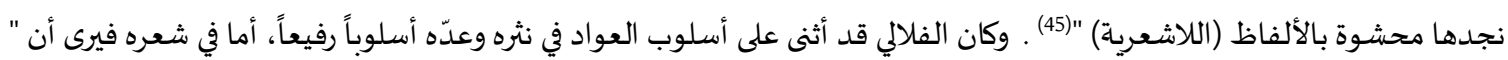

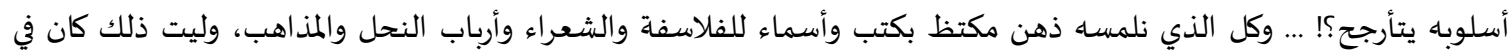

$$
\begin{aligned}
& \text { صياغة حسنة، أو أسلوب قوي بارع !!" (46) .ويورد له من الشعر الركيك قولهيه: }
\end{aligned}
$$

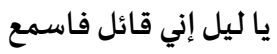

$$
\begin{aligned}
& \text { هذا زرادشت، وماني معي }
\end{aligned}
$$

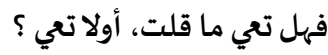

$$
\begin{aligned}
& \text { قد شوها حسنك لي يا ظلام فهل ترى يا ليل أني لا أنام؟ أولام } \\
& \text { أولا ترى، لا ريب أنت العزيز }
\end{aligned}
$$

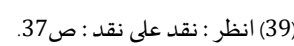

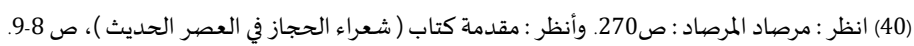

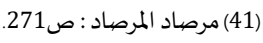
(42) المرصاد : صرصاد المرصاد :ص134-135.

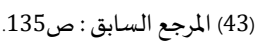
(44) العمدة في محاسن الشعر وآدابه ونقده : ج1، ص135) ص124.

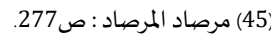
(46) المرصاد : ص159, مرصاد المرصاد صا صعدها . 


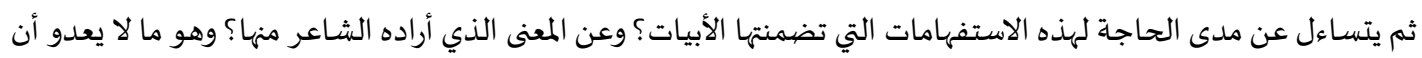

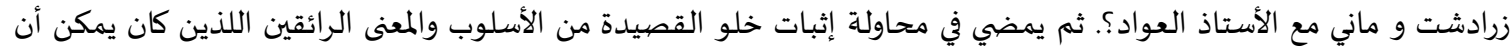

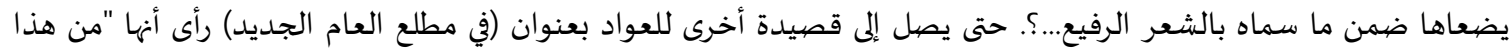

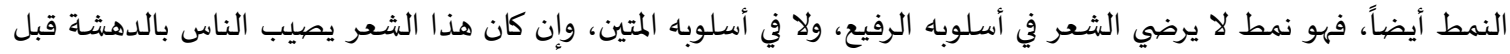

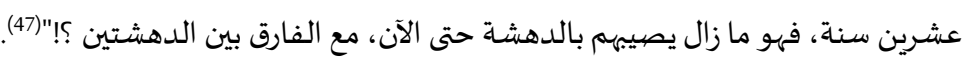

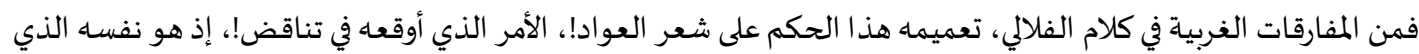

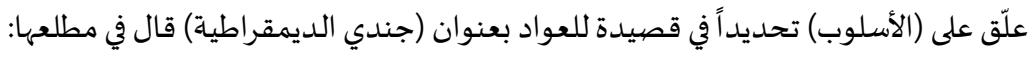

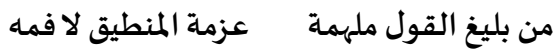

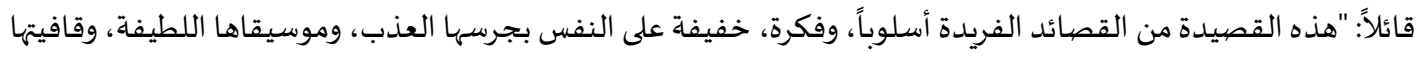

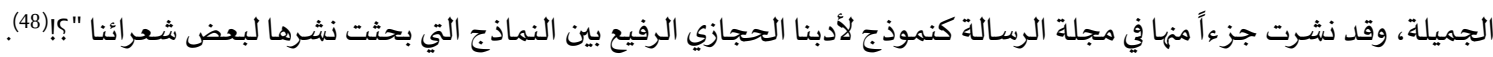

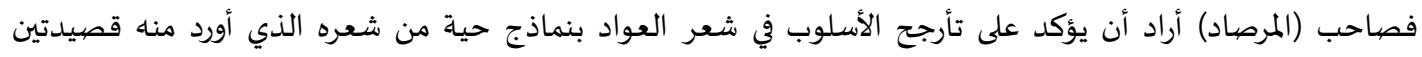
متأرجحتين في الأسلوب بين الركاكة والمتانة . ومن ركاكة الأسلوب وفضاضة المعنى ينطلق الأستاذ عبدالجبار في اعتراضها على إطراء الفلالي وإعجابه بجملة للكاتب عدانان

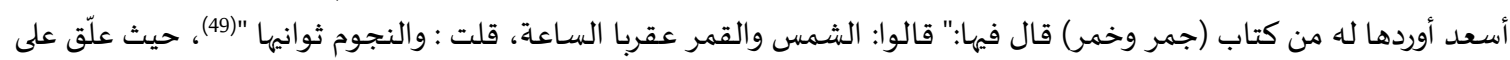

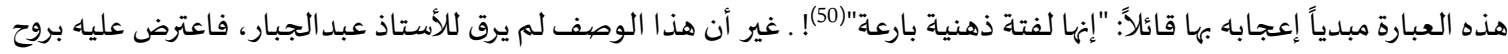

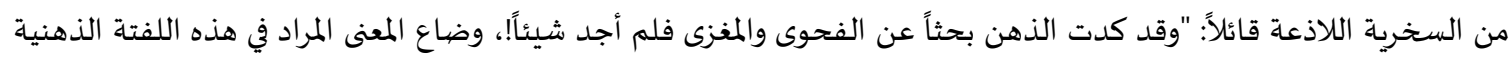

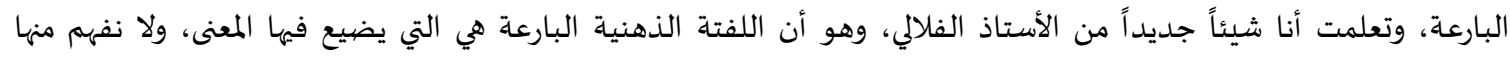
شيئًا؟!"(51).

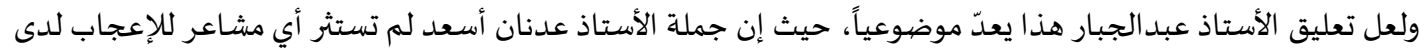

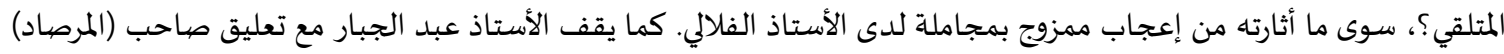

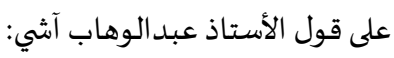

\section{دعاني أساجل أحرارها وقوماً لنقفوا آثارها}

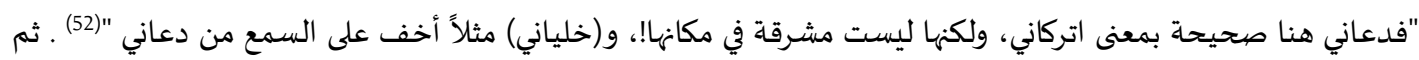

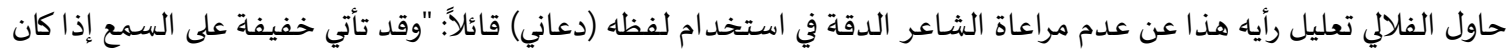

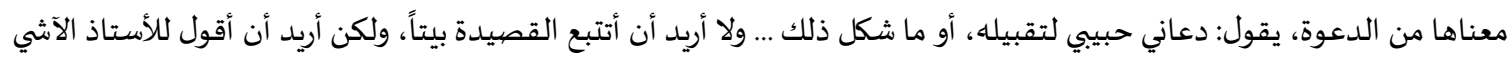

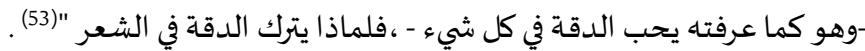

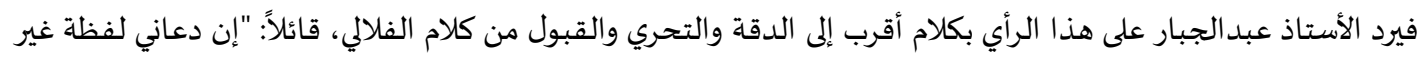

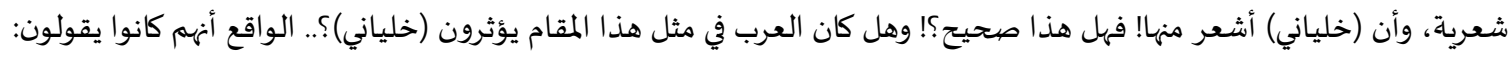

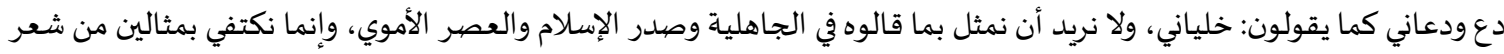

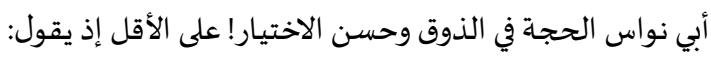

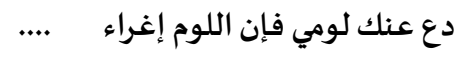

وإذ يقول:

\section{دعيني أكثر حاسديك برحلةٍ إلى بلدٍ فيه الخصيب أمير"(54)}

ويختم الأستاذ عبد الجبار نقده بعض آراء الفلالي بوصف دقيق برحلة وصف باه السمات الخاصة التي تميز بها نقد صاحب (المرصاد) 
في مرصاده قائلاً: "وهذا البهلوان قد تميز بسمات خاصية في نقده , فهو يمزج القسوة بالظرف وروح الفكاهة، إنه قاسٍ، ولكنها بعيد عن

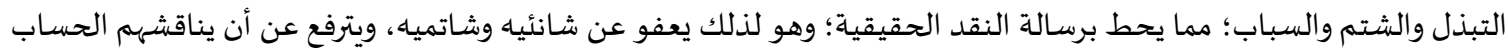

... فحياك الله يا صاحب المرصاد، وحيا في شخصيتك المكافح البهلوان الحر الكريم، وإلى اللقاء في معركة قلمية أخرى "(55 وهون.

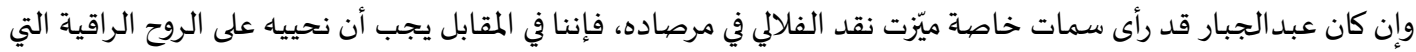
اتسم بها أيضاً من خلال ما ذكره في خاتمته هذه، التي تؤكد على تأثره المشرف بسمات مات ما يمكن أن يقال في تراثنا العربي في مثل هذا المقام "(56)

\section{نقد النقد في المقالات الصحفية}

ليس من شك في أن الصحافة العربية، والسعودية -على وجاء الخصوص- كانت حاضينة للنقد بكافة اتجاهاته وقضاياه، وتحديداً في الفترة من أواسط القرن الرابع عشر الهجري -ومع ظهور العدد الأول من صحيفة أم القرى عام 1344هـ -وحتى قبيل نهايته.

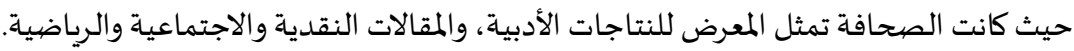

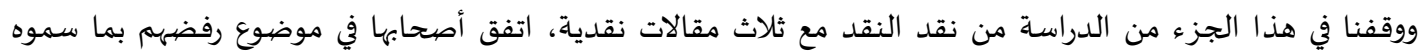

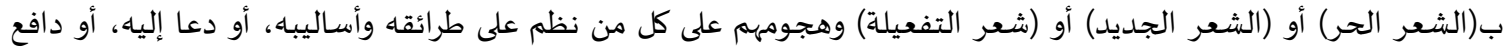
عنهاوأصحابها هم الشاعران: حسين سرحان وحسين عرب، وثالهما هو الأستاذ عبدالسلام الساسي. وقد نشر الثلاثة مقالاتهم

بصحيفة البلاد.

وسنعرض بداية الآراء النقدية في هذا الموضوع للنقاد الثلاثة دفعة واحدة، ثم نورد نقد الأستاذ عبد الجبار وردوده عليهه، بعد

ذلك يحاول الباحث التوجياء والترجيح بين النقدين وفق نظرة تحليلية موضوعية.

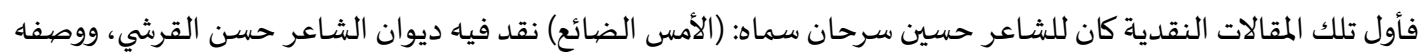

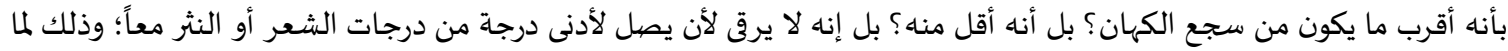

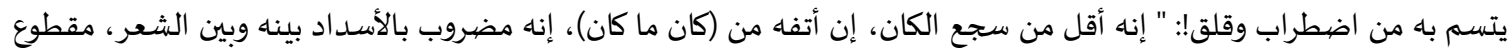

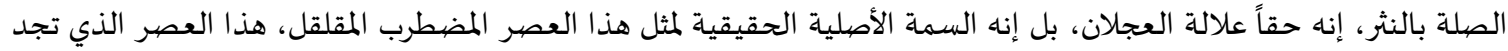

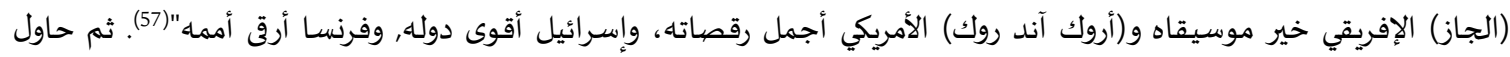

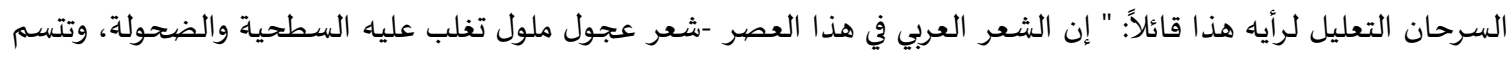

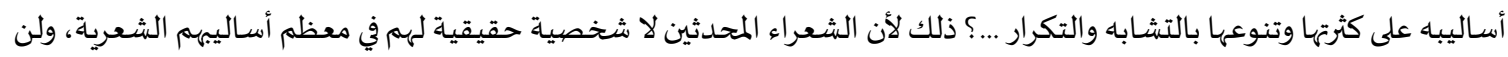

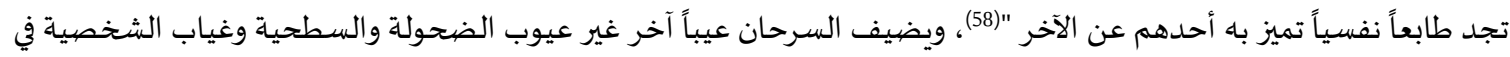

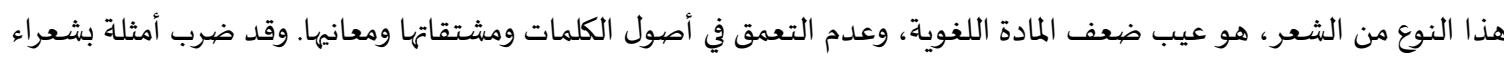

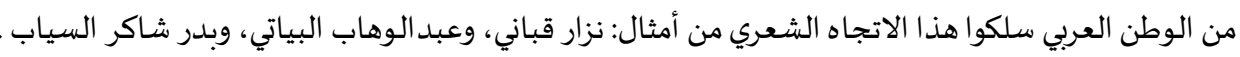

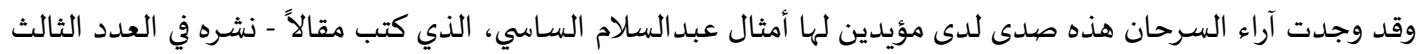

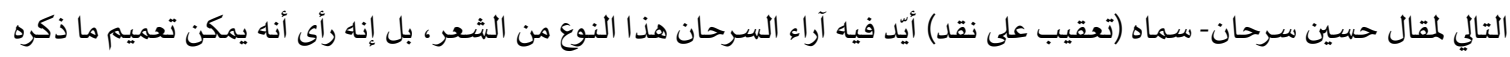
على كل شعر تنطبق عليه العيوب التي أوردها السرحان: من فقدان للشخصياة، وضعف في اللغة، وشيوع للسطحية، وضحالة في المعاني (59) ثم عرض نماذج من الشعر العربي (ي الصحيح) للمتنبي وابن الرومي وأبي العلاء؛ هادفاً إلى المقارنة بينه وبين ما سماه

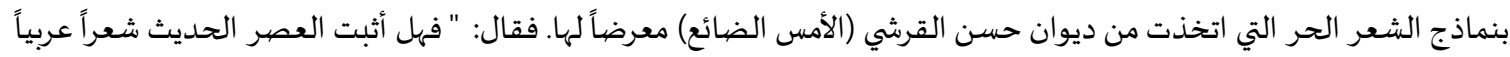

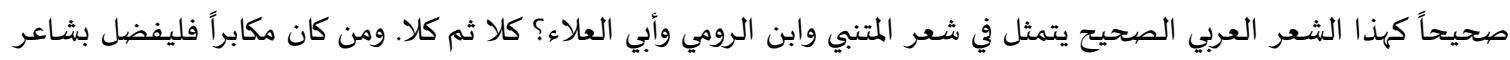

واحد يأتي بنفس واحد كهذه الأنفاس العالية التي ظل ولا يزال أريجها يعبق في الدنيا بأسرها حتى يرث الله الأرض ومن عليه اليها "(60).

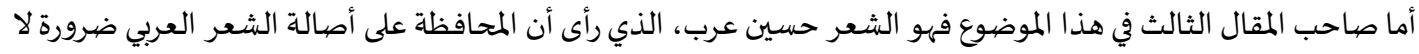

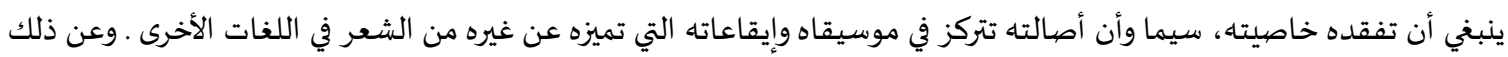

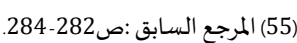
(56) انظر : على سبيل المثال : ( النقض على ابن وكيع في شعر المتنبي وتخطئته ) ، ( نصرة الثائر على المثل السائر ) .

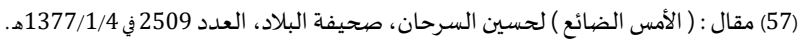

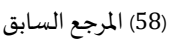

(59) انظر : مقال : (تعقيب على نقد) لعبد السلام الساسي، صحيفة البلاد , العدد 2512 في 1377/1/8هـ (60) المرجع السابق. 


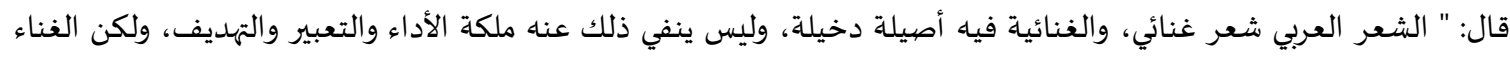

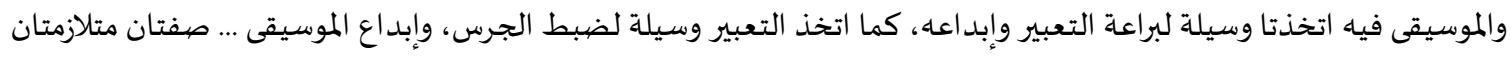

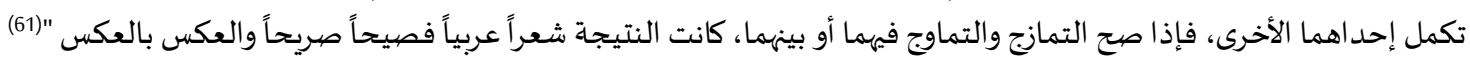

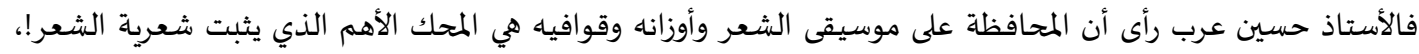

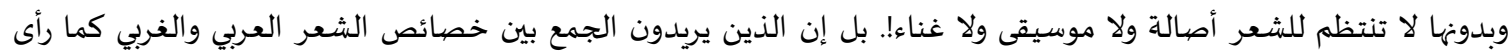

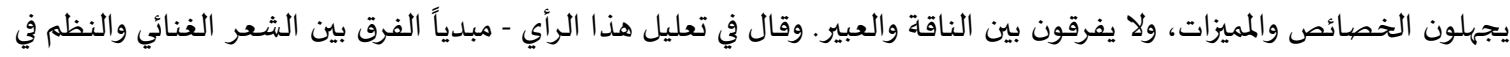

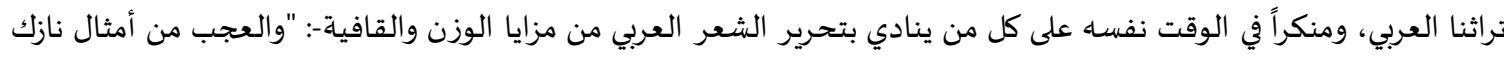

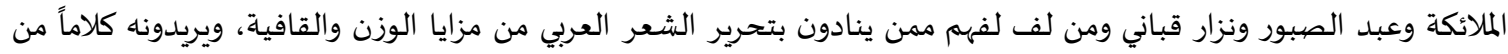

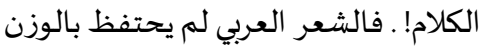

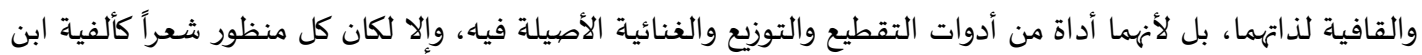

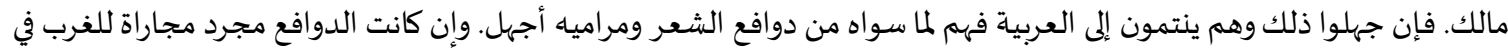

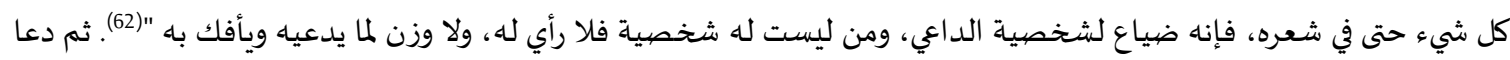

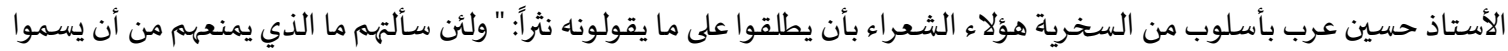

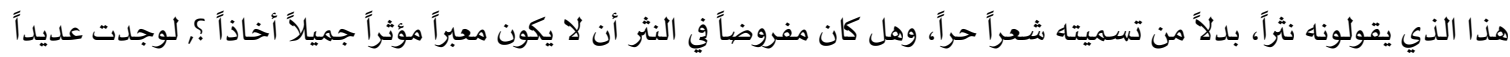

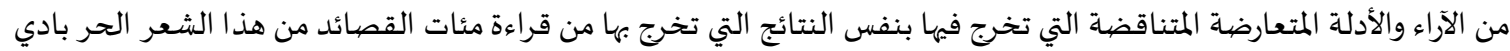

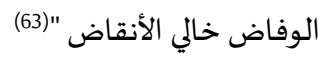
وبعد، فهذه مادة النقد حول ما سميت بقضية (الشعر الحر)!، جمعتها مقالات ثلاثة، كتها من يعدّون ضمن رواد الشعر

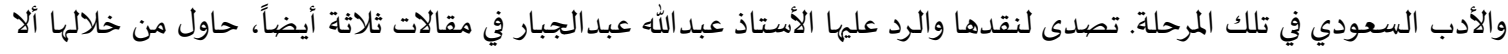

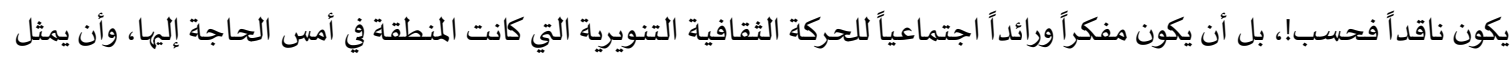

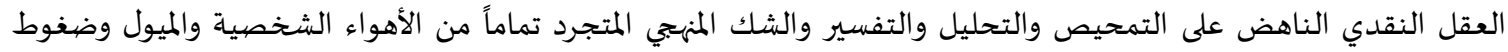

اللحظة العابرة"(64) .

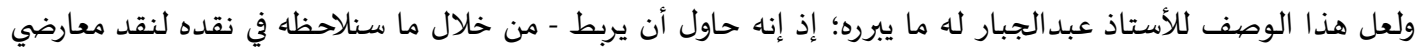

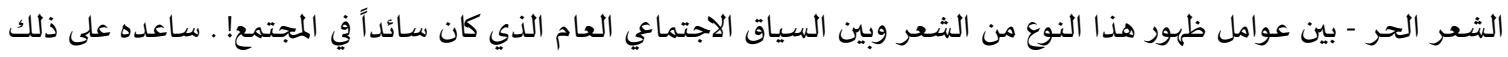
ثقافته الواسعة، واطلاعه على النتاج الأدبي العربي والغربي.

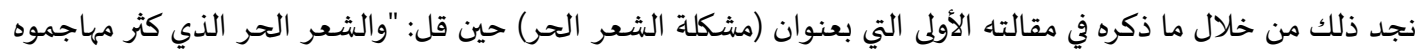

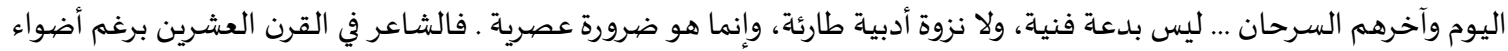

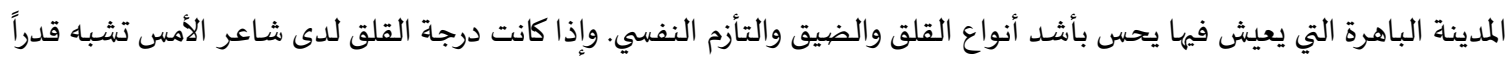

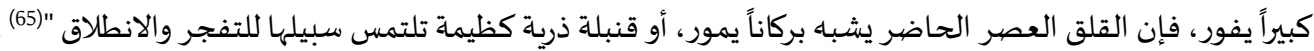

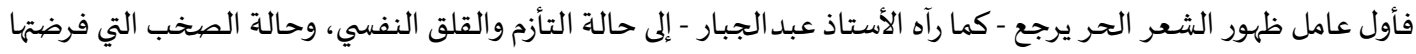

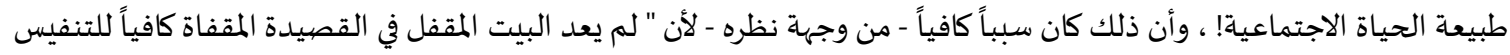

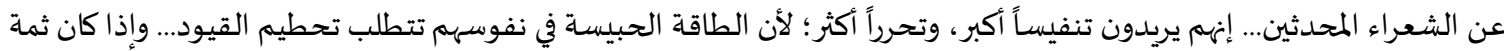

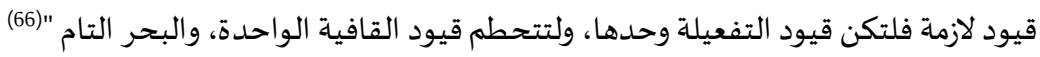

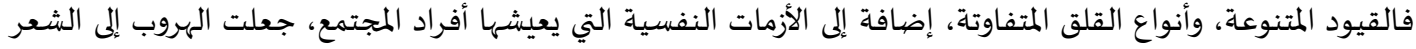

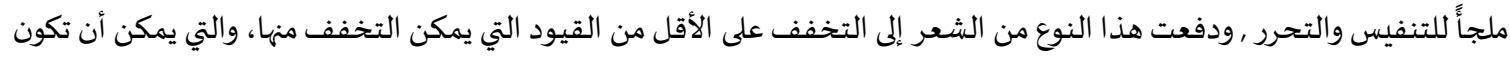

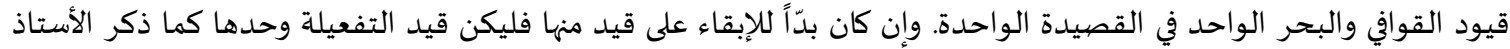


وكانت الشاعرة العراقية نازك الملائكة قد عقدت فصلاً من كتابها (قضايا الشعر المعاصر) تحدثت فيه عن الجذور

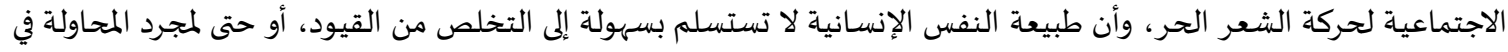

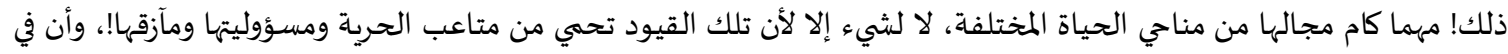

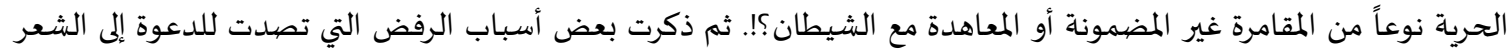

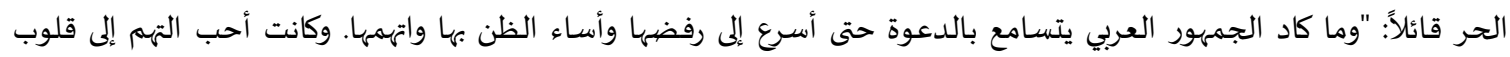

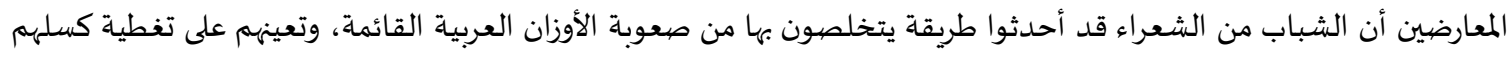

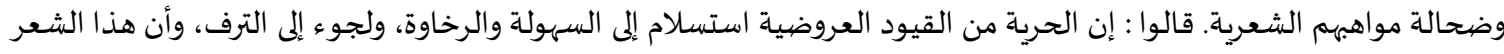

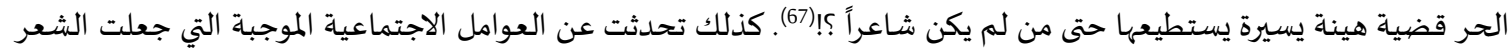

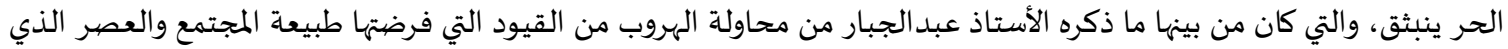

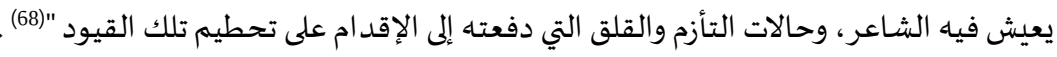

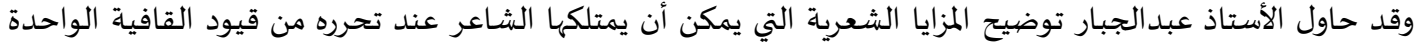

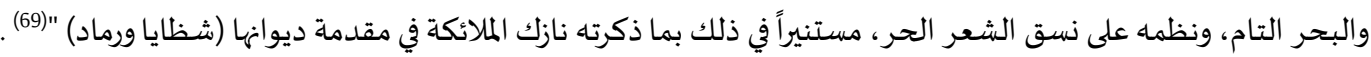

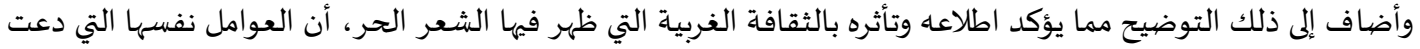

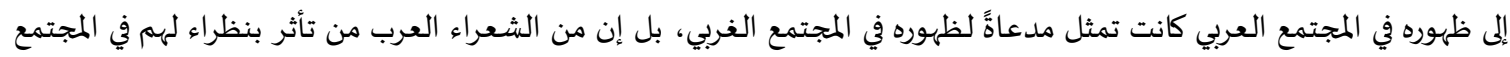

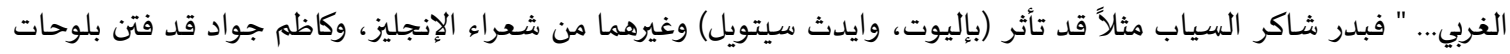

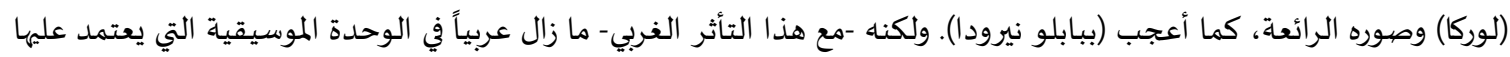

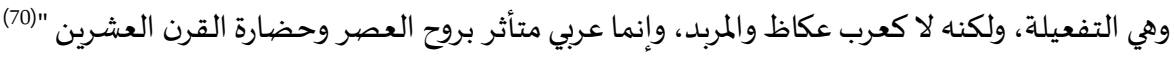

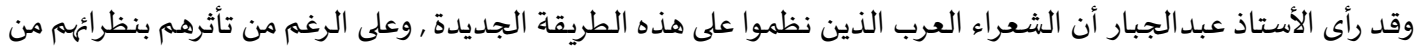

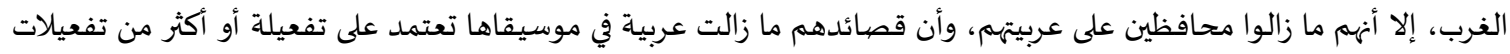

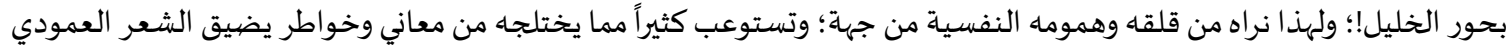

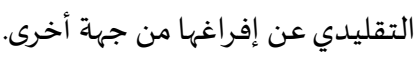

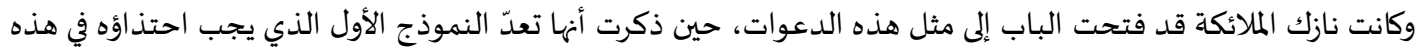

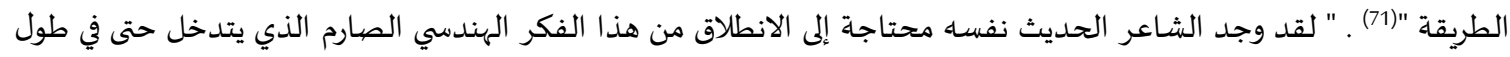

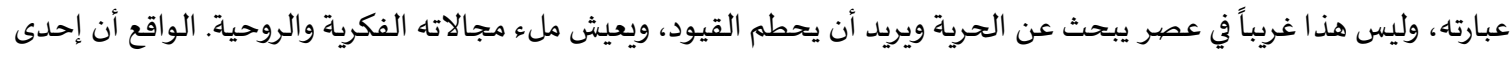

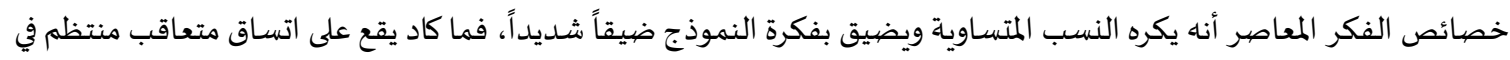

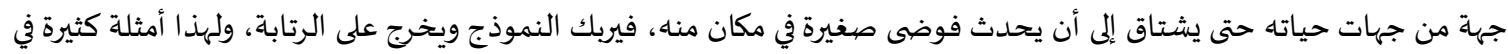

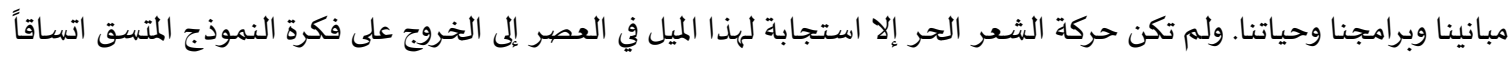

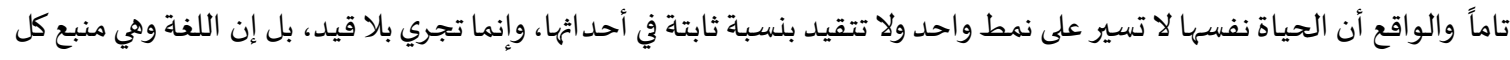

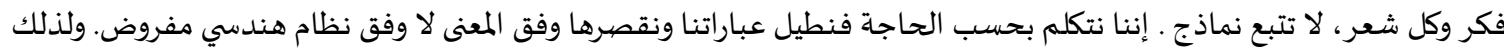

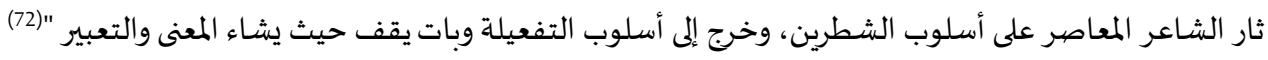

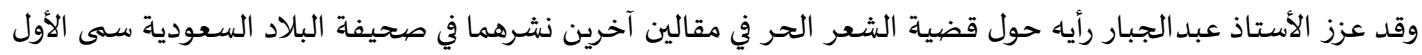

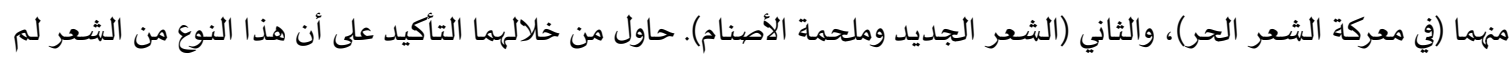

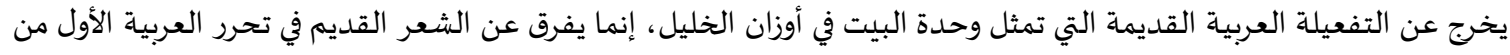

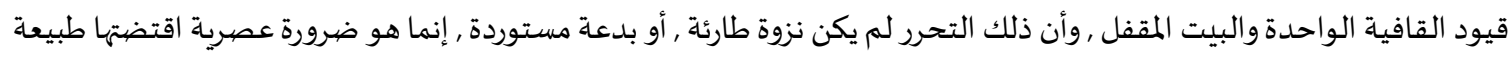

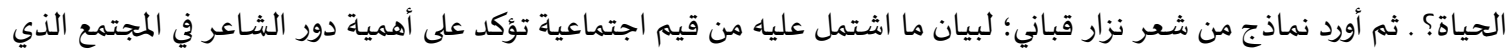

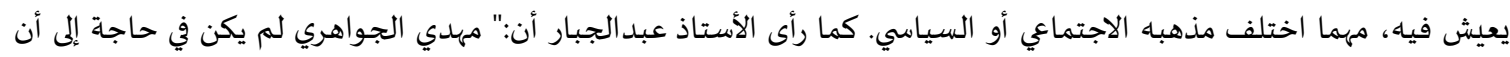

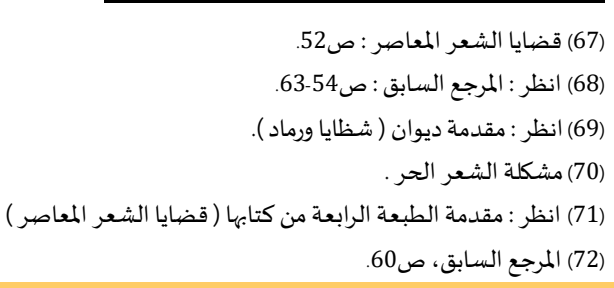


ينظم على الطريقة الجديدة ليكون يسارياً، بل إنه نظم على الطريقة العمودية التي يعتز بها ويضمن إطاره التقليدي أفكاره التقدمية،

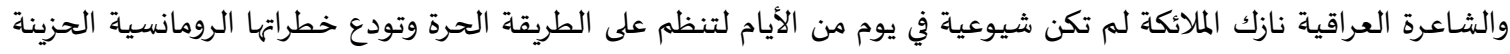

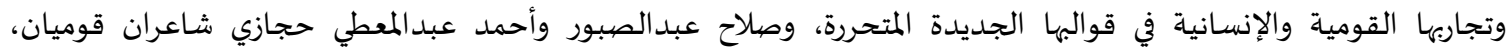

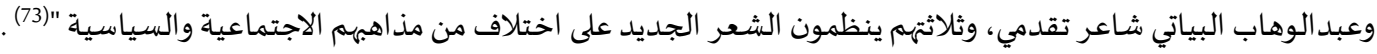

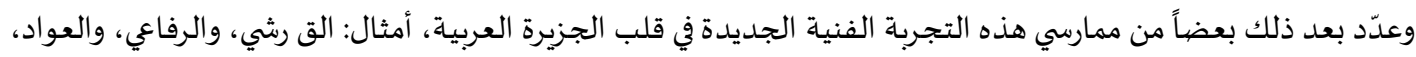

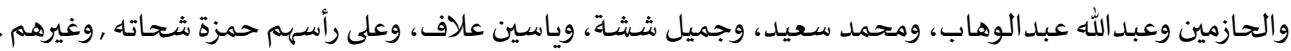

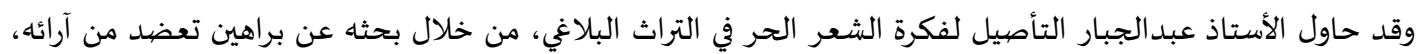

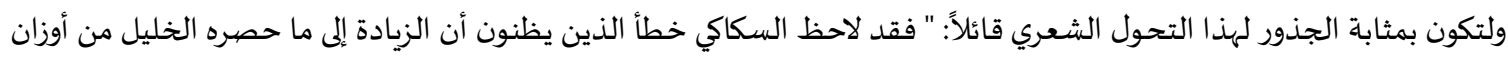

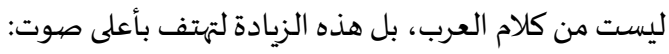

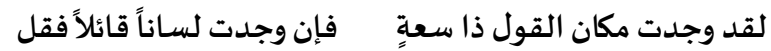

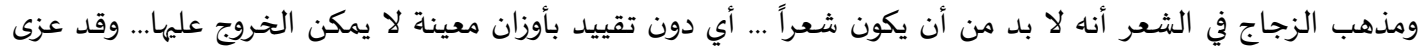

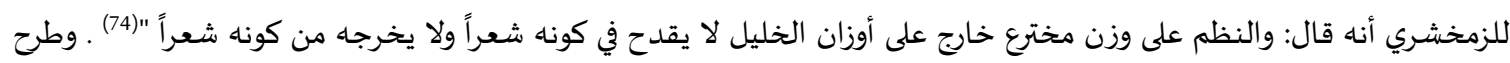

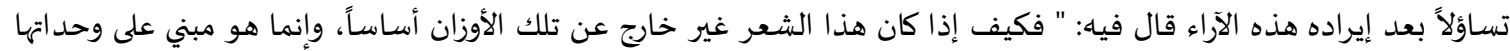

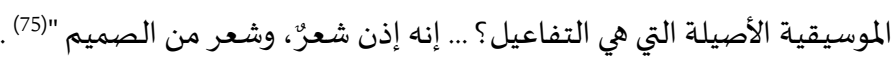

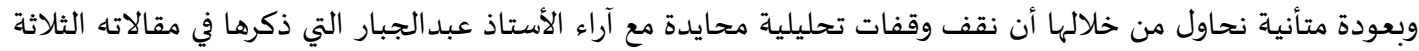

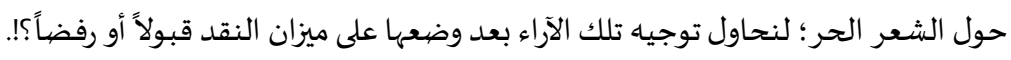

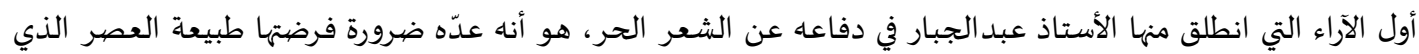

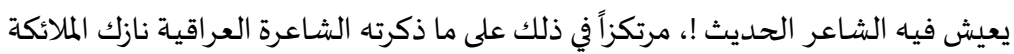

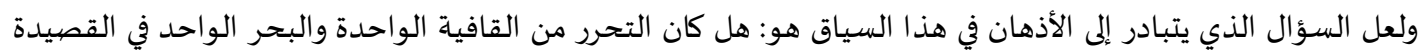

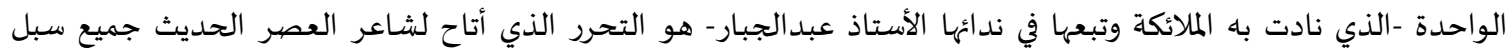

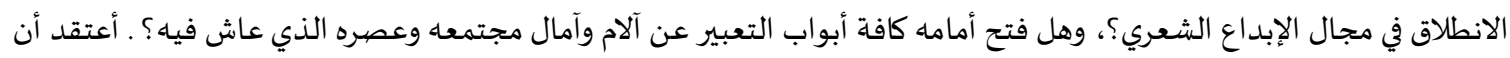

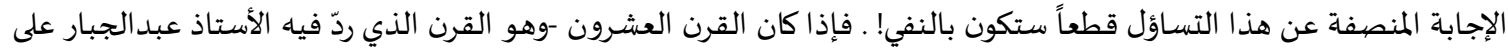

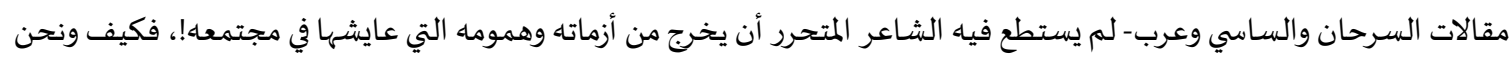

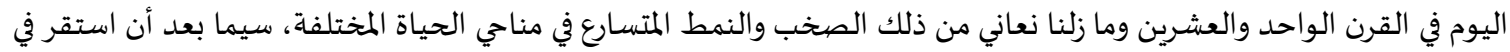

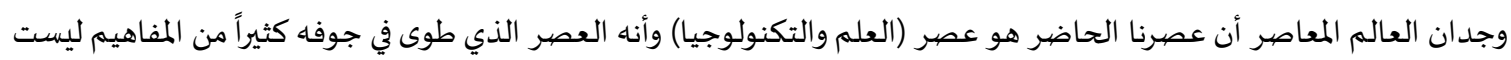

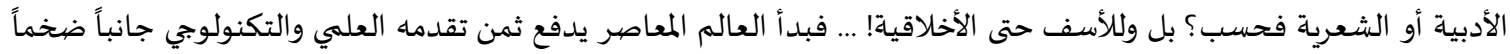

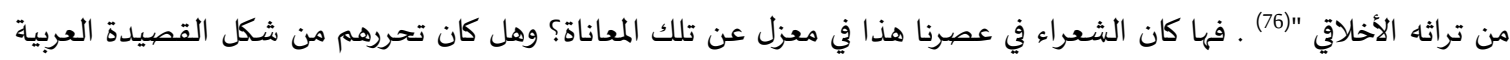

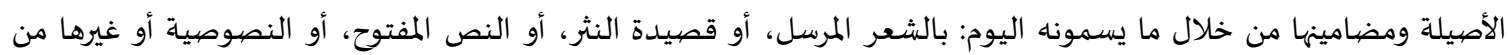

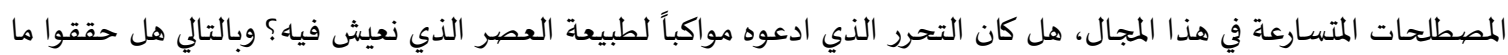

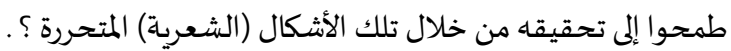

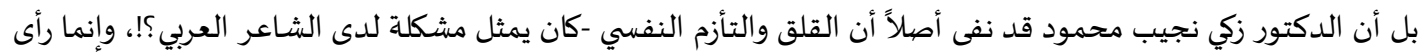

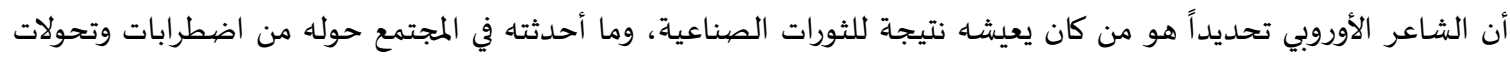
وتغيرات " (77).

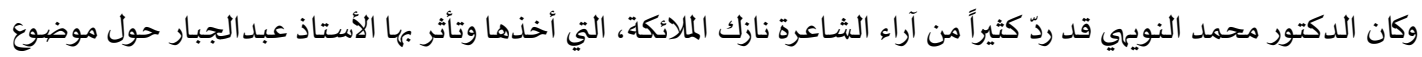

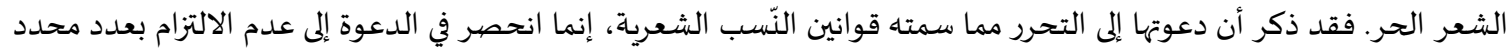

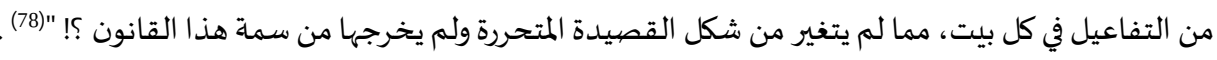

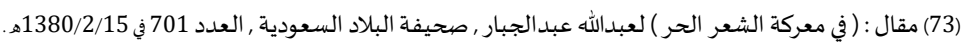

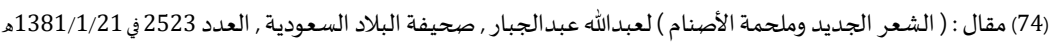

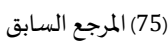

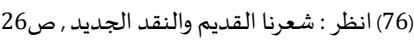

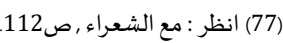

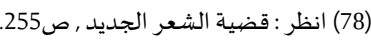


بل أن الملائكة نفسها قد عدّت أن من عيوب الشعر الحر اقتصاره على ثمانية بحور من بحور الشعر العربي الستة عشر،

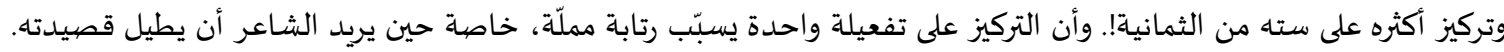
ولهذا رأت أن الشعر الحر لا يصلح للملاحم قط "ألى "(79) . كما أضافت وبروح المنصف في الرأي أن : "مؤدّى القول في الشعر الحر أنه لا ينبغي أن يطنى على شعرنا المعاصر كل الطغيان؛ لأن أوزانه لا تصلح للموضوعات كلها، بسبب القيود التي تفرضها عليه وحدة التفعيلة وانعدام الوقفات، وقابلية التدفق والموسيقية.

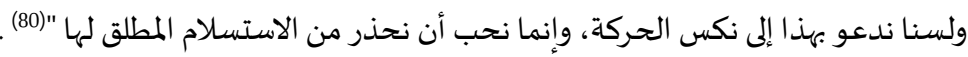

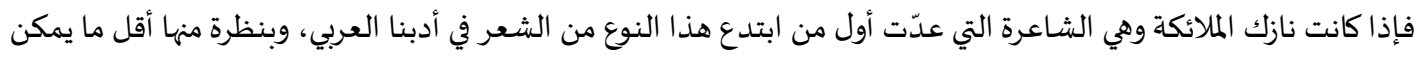
أن توصف بأنها نظرة إنصاف، أكّدت على أنه لا ينبغي الانجراف الكامل مع الشعر الحر , للأسباب التي ذكرتها، فكيف بالئ فالأستاذ

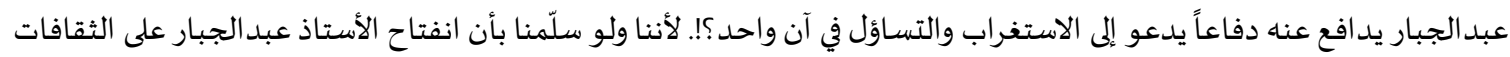

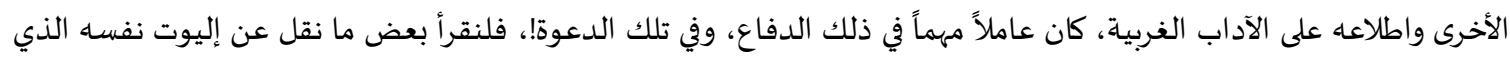

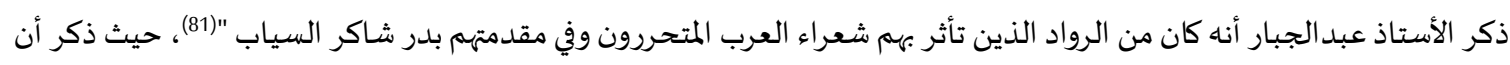

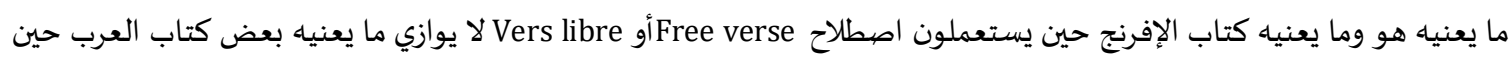

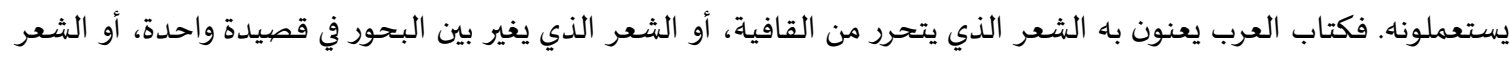
الذي يغير عدد التفاعل من بيت إلى بيت.

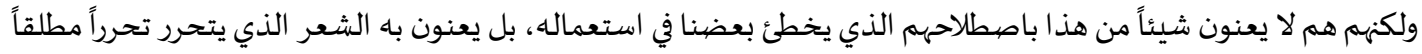

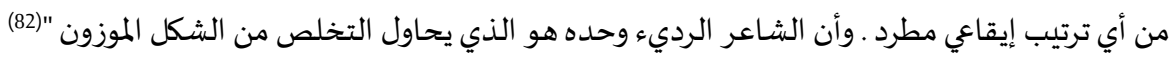

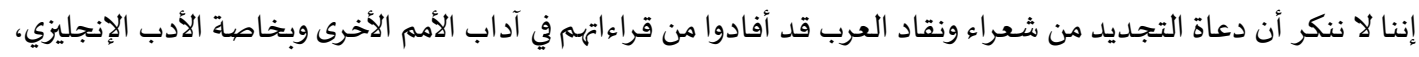

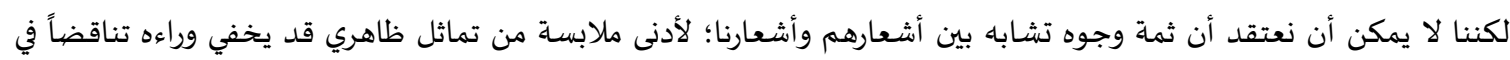

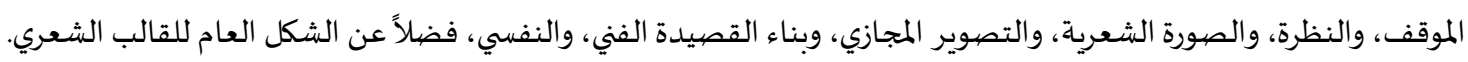

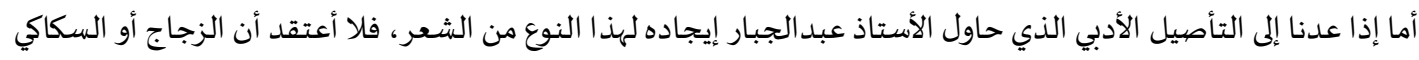

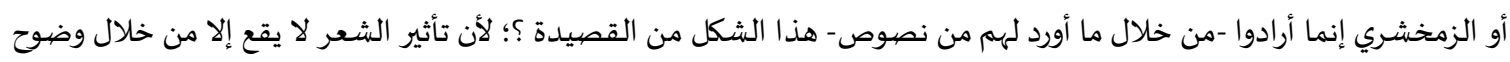

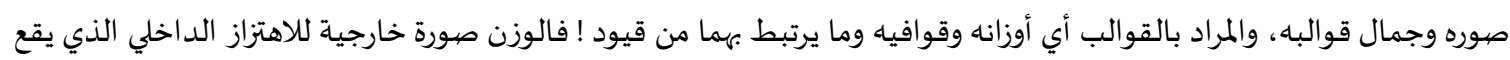

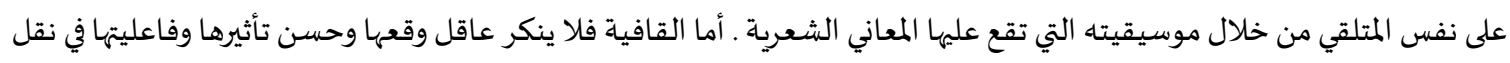

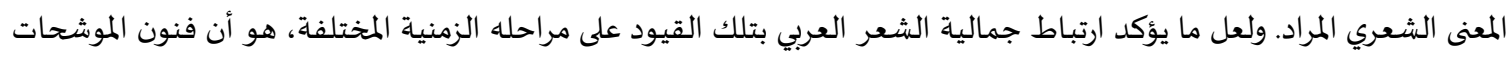

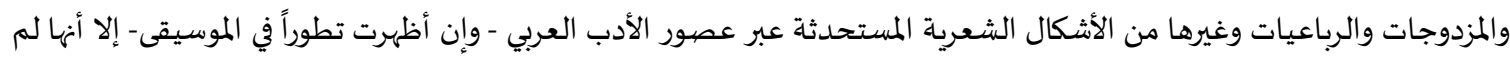

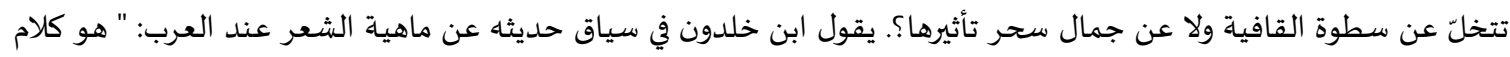

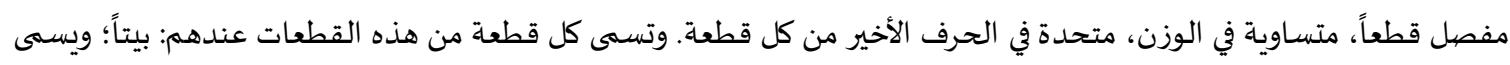

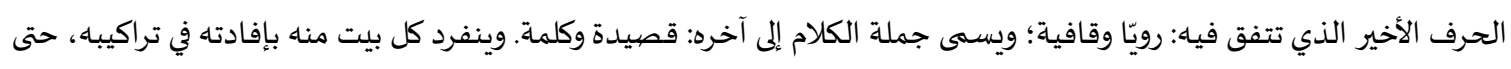

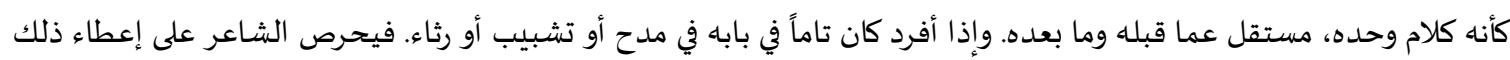

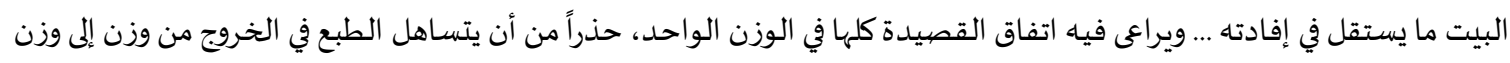

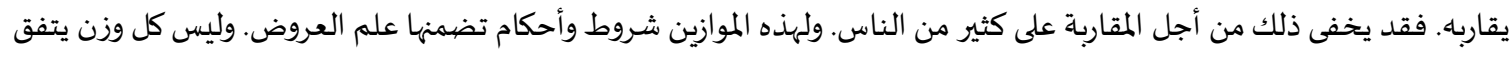

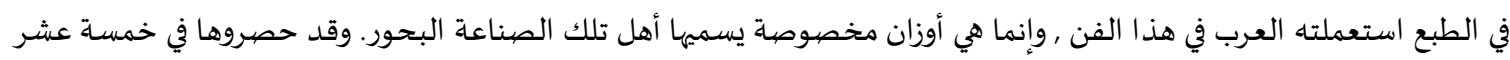

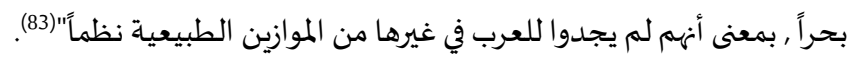
فإذا كانت هذه هي هذه ماهية الشعر عند ناقد متأخر من نقاد العرب، اشتهر بالاطلاع على ثقافات الأمم الأخرى إضافة إلى المانى

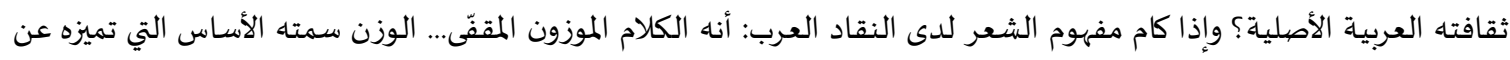

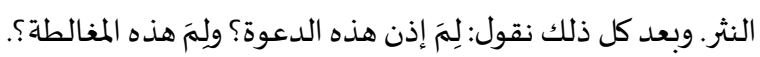

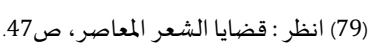

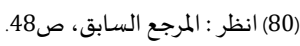

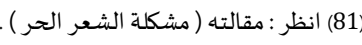

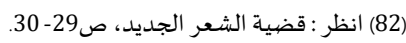

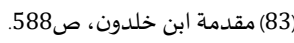


وقد أكّد الأستاذ عباس العقاد على المكانة المهمة للقافية في شعر العرب، وطربها في أذن السامع حين تأتي في مكانها المتوقع،

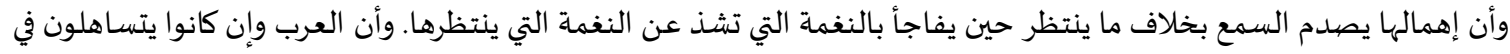

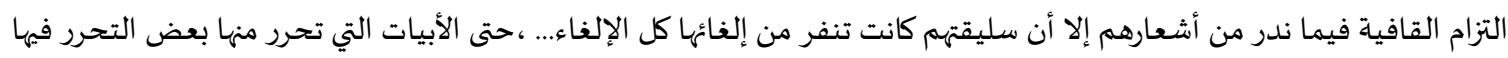

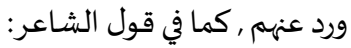
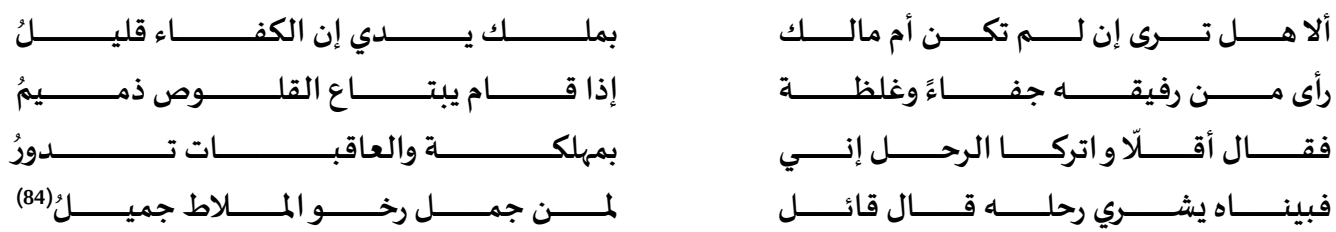

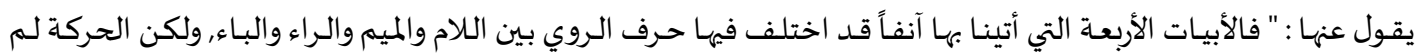

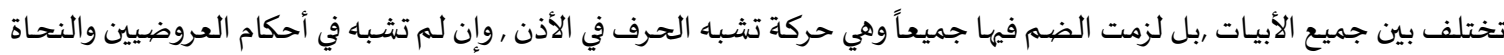

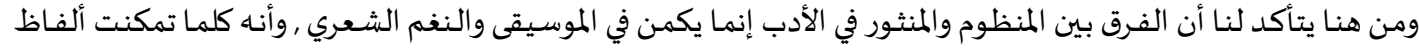

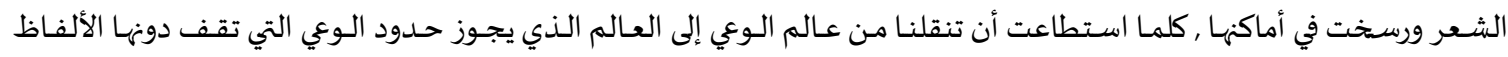

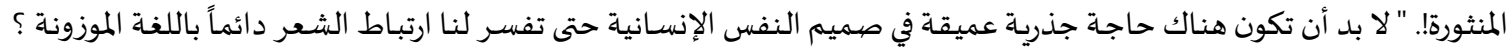

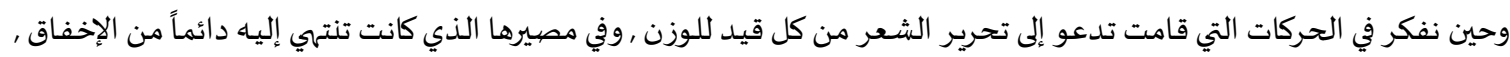

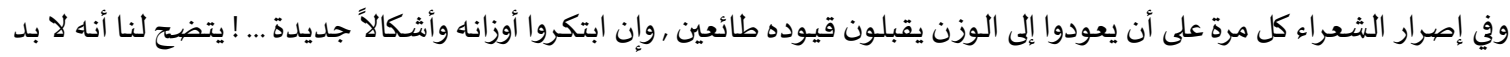

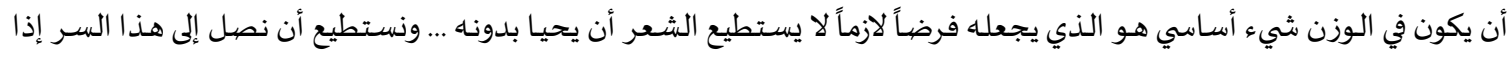

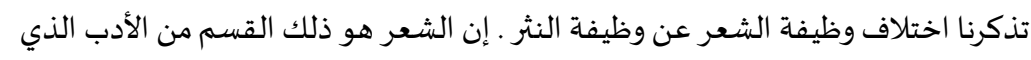

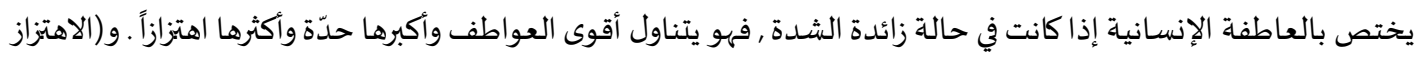
) هو السمة الأولى للعاطفة , والسمة الأولى للوزن "(86) .

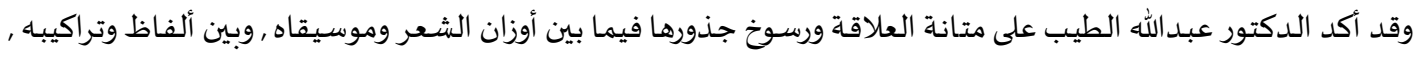

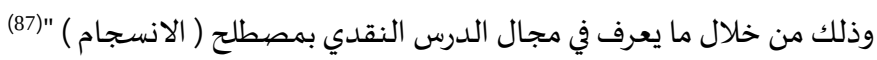

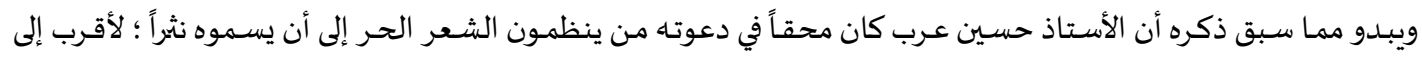
سماته من سمات الشعر (88).

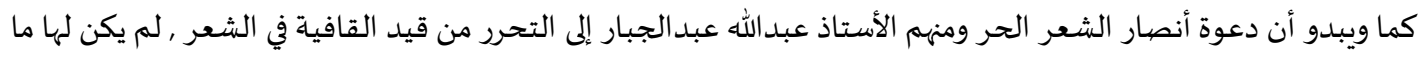

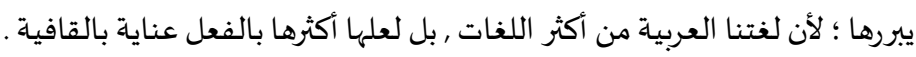

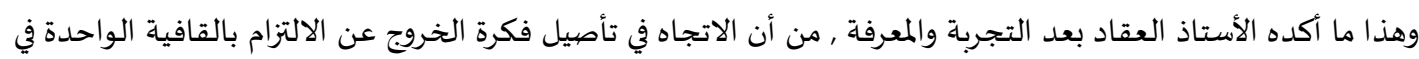

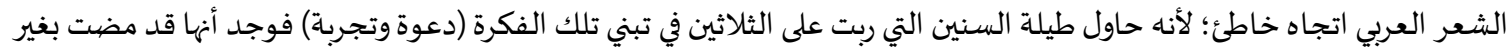

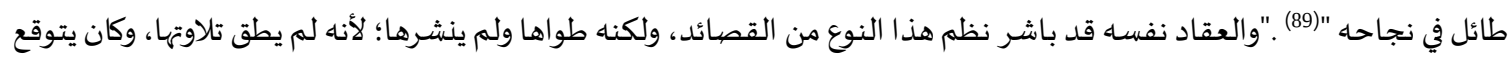

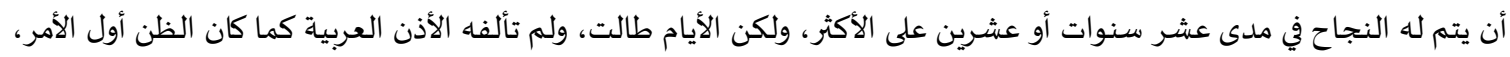

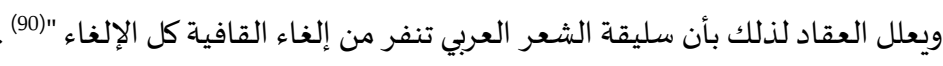

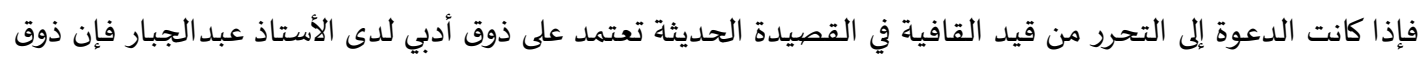

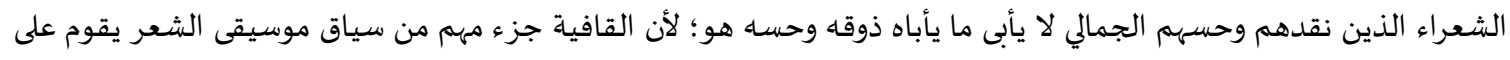

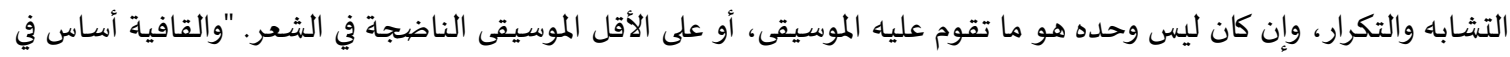

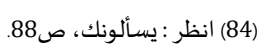

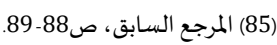

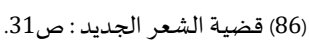

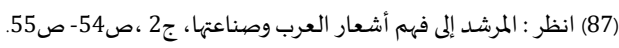

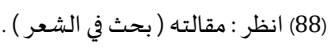

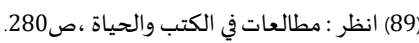

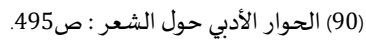


الشعر العربي، حتى كان القدماء يزعمون أن الشعر هو كلام الموزون المقفى، ولا يكفي في الشعر أن تنتهي أبياته بحرف واحد، بل يجب أن تكون حركته واحدة "(91).

إن الوزن والقافية في الشعر ليس شيئاً زائداً يمكن الاستغناء عنهن وليس مجرد شكل خارجي يكسب الشعر زينة ورونقاً وطلاوة وحلاوة؟ ... بل هما ضرورتان تقوم عليهما حقيقة جذرية في صميم التكوين والسلوك البشريين، وإن الخطأ كل الخطأ أن ينظر

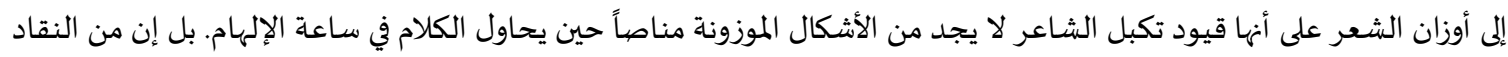

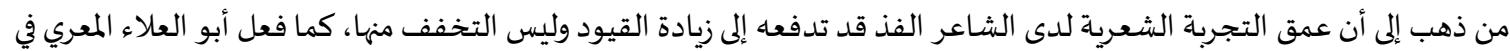
لزومياته.

ولقد كانت نازك الملائكة قد تنبأت في عام 1954م بأن حركة الشعر الحر ستقدم في السنين القادمة حتى تبلغ هايتها المبتذلة،

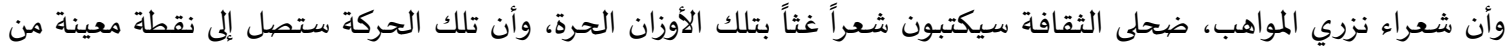

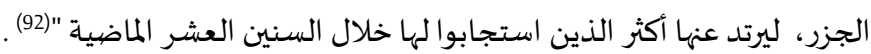
ولسنا نعني من خلال هذا السياق من الدراسـة إنكار الانفتاح أو تلاقح الرؤى والاتجاهات بين الآداب المختلفة؛ لأن ذلك يعد المدان

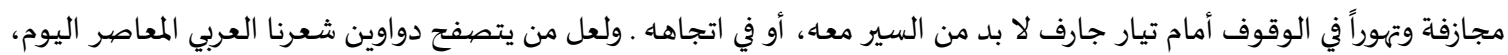

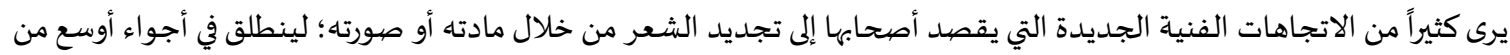

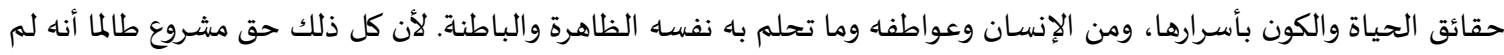

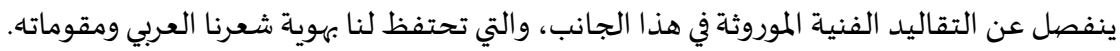

الخاتمةة:

هدفت هذه الدراسة إلى إبراز موضيوع مهم من موضوعات الدراسات النقدية المعاصرة، هو موضيوع (نقد النقد). ولعل تاريخ

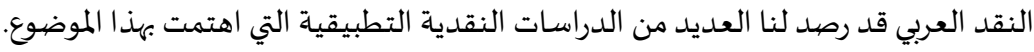
ولا غرابة في ذلك، فالنقد الأدبي هو أكبر أنواع الأدب الوصفي. وإذا كان في الناس الكثير ممن يرضى عن نفسسه، فإن أقل القليل منهم من يرضى عن غيره. وعدم الرضا عن الغير في مجال الرأي نقدا.

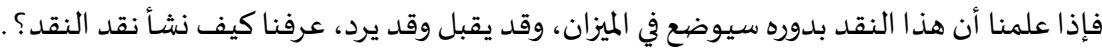

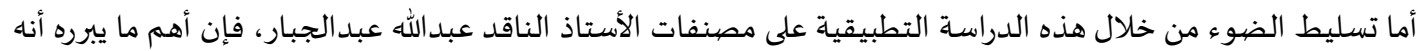
ناقد من العصر الحديث لم يرتهن إلا إلى الكلمة الصادقة؛ فأصبح قيمة في الفكر، وقيمة في السلوك ,ونموذجاً للمثقف الذي لادئل يتلون ولا يداهن.

$$
\text { ولعل من أبرز ما توصلت إليه هذه الدراسة من نتائج ... ما يلي: }
$$
• أن الاهتمام بالأدب والنقد لدى الأدباء والنقاد السعوديين بدأ ينمو ويزدهر بعد قيام الدولة السعودية الثالثة في عام 1319هـ ،

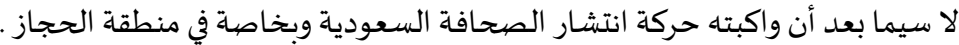
أن الخطاب النقدي المنشور في الصحافة السعودية آنذاك يعدّ تعبيراً عن حركة الإصلاح والتغيير الاجتماعي في مناحي الحياة

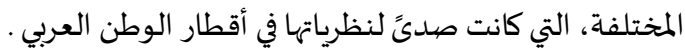
أن المقالات النقدية التي انتشرت في تلك الفترة كانت تتسم -في أكثرها- بالخصومات والمناوشات سواء مع أشخاص بأعينهم، أو مع تيارات أدبية معينة؛ تأثراً بالمعارك الأدبية التي كانت تحدث على صفحات الصحف في في بعض التهات الأقطار العربية. أن أكثر آراء الأستاذ هاشم الفلالي النقدية كانت تتسم بالتأثرية والانطباعية والعمومية أكثر من غيرها من المقاييس الفنية للنقد. أن النقاد السعوديين -على وجاء العموم- والأستاذ عبدالله عبدالجبار -على وجاء الخصوص- قد تأثر بجملة من الآراء النقدية في مصر والشام والعراق والمهجر. أن ثقافة الأستاذ عبد الله عبدالجبار العربية والغربية، وغزارة اطلاعها , وقضياءه فترة من حياته بمصر، كان لها تأثيرٌ واضحُ على آرائه النقدية. • أن الدعوة إلى التجديد في الشعر العربي لم تثبت طويلاً، وبخاصة بعد أن تأكد أن القافية والوزن ركنان أسـاسيان فيه. 
ولهذا فإن الدراسة توصي بضرورة توجه الباحثين للكشف عن الجهود النقدية المبثوثة في عدد غير قليل من أشكال فنون الأدب للنقاد السعوديين، وإبرازها، ودراستها، ومقارنتها بآراء أعلام النقد في وطننا العربي الكبير من نواحي تنظيرية وتطبيقية متعددة. وتوصية أخرى إلى وزارة التعليم بالمملكة العربية السعودية للاستفادة من المقترحات التربوية المتميزة التي أشعل بها الأستاذ

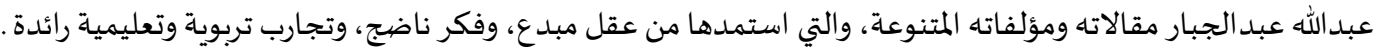

المراجع:

$$
\begin{aligned}
& \text { 1. أبو الأنوار، محمد (1987). حركة الشعرفي العراق. ط2. دار المعارف. القاهرة. }
\end{aligned}
$$

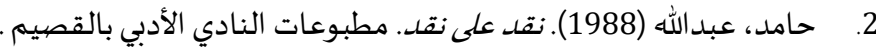

$$
\begin{aligned}
& \text { 3. حسين، طه (1954). التوجيه الأدبي. دار الكتاب العربي. بيروت . }
\end{aligned}
$$

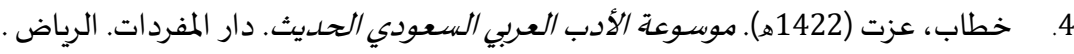

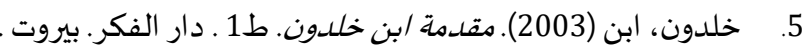

$$
\begin{aligned}
& \text { 6. رومية، وهب أحمد (1996). شعرنا القديمروالنقل الجلديل. سلسلة عالم المعرفة. الكويت . } \\
& \text { 7. } \\
& \text { 8. }
\end{aligned}
$$

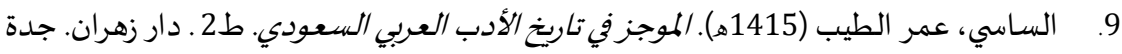

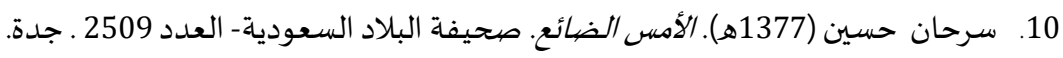

$$
\begin{aligned}
& \text { 11. شاكر، محمود محمد (1996). نمط صبعب ونمط مخيف. ط1 ـ ـ مطبعة المدني. القاهرة. }
\end{aligned}
$$

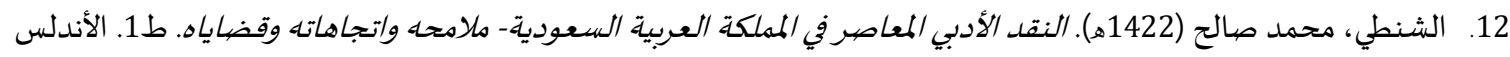

$$
\text { للنشر والتوزيع. حائل . }
$$

13. الصبان، محمد سرور (1383هـ). أدب الحتجاز. ط3 ـ دار الأصفهاني وشركاه. جدة.

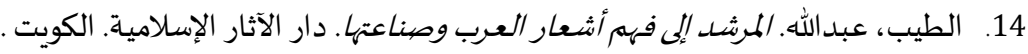

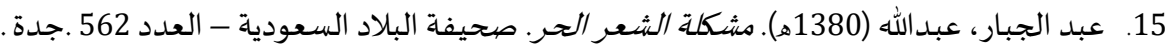

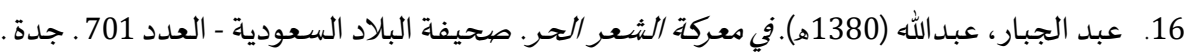

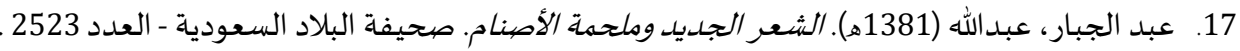

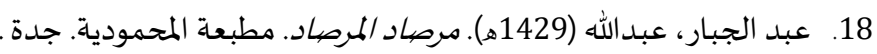

19. عرب، حسين (1380هـ). بحث في الشعر. صحيفة البلاد السعودية - العدد 653. جدة جدة.

20. العقاد، عباس محمود. مطالعات في الكتب والحيات. دار الكتاب العربي. بيروت .

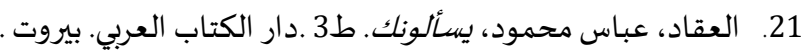

22. العكبري، أبو البقاء. شرح ديوان أبي الطيب المتنبي. ضبط وتصوديحيح: مصطفى السقا - إبراهيم الأبياري- عبد الحفيظ شلبي، دار

$$
\text { المعرفة، بيروت . }
$$

23. فقيهي، أحمد عائل (1432ه). عبدالله عبد الجبار استثنائي في الزهن الغابر. صحيفة عكاظ - العدد 3620 ـ جدة .

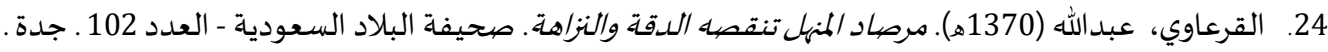

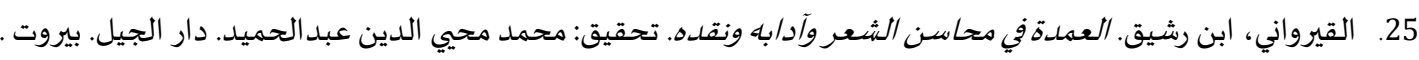

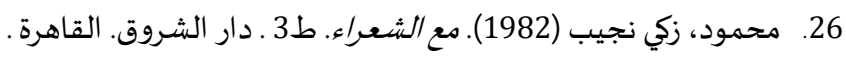

27.

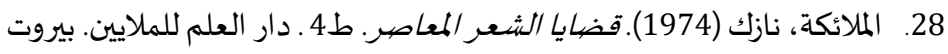

29. النويهي، محمد (1971).قضضية الشعر الجدايل. ط2 ـ ـ دار الفكر. القاهرة . 
International Journal for Arabic Linguistics and Literature Studies (JALLS)

www.refaad.com

Journal Homepage: https://www.refaad.com/views/JALS/home.aspx ISSN: 2663-5860(Online) 2663-5852(Print)

\title{
Critiquing critique By Abdu-Allah Abdul-Jabbar
}

\author{
Yasir Sulaiman Shosho \\ Associate Professor at Rhetoric and Literature Critique Department, Arabic Language College \\ Umm Al-Qura University, KSA \\ ysshosho@uqu.edu.sa
}

Received : 20/3/2021 Revised : 15/4/2021 Accepted : 30/4/2021 DOI : https://doi.org/10.31559/JALLS2021.3.1.3

Abstract: This study aims at the most common aspect of contemporary critique studies (critiquing critique). Hence, Arabic critique history has spotted plenty of applied critique studies tackling with the same issue.

No wonder that the literature critique is the largest among descriptive literature types and if many people are satisfied with themselves, only few are satisfied with others. This unsatisfaction or having different views with others is called critique.

Knowing such critique is to be scaled, accepted or not, we would figure out how critiquing critique had first started.

Although he was influenced by Arabs and non-Arab's critics, critic Abdu-Allah Abdul-Jabar proves throughout this applied study on his books, in general, and through his book (Mersad Almersad), in particular, that he is a prominent critic in modern era, dedicated only to true wordings so became intellectually and behaviorally valuable, a model of an educated figure who never flatters nor compromises.

Keywords: Critique; Literature critique; Critiquing critique; Abdu-Allah Abdul; Jabbar; Al Mersad; Mersad Almersad.

\section{References:}

1. 'bd Aljbar, 'bdallh (1380h). Mshklt Alsh'r Alhr. Shyfh Alblad Als'wdyh - Al'dd 562. Jdh .

2. 'bd Aljbar, 'bdallh (1380h). Fy M'rkt Alsh'r Alhr. Shyfh Alblad Als'wdyh - Al'edd 701. Jdh .

3. 'bd Aljbar, 'bdallh (1381h). Alsh'r Aljdyd Wmlhmh Alasnam. Shyfh Alblad Als'wdyh - Al'dd 2523.

4. 'bd Aljbar, 'bdallh (1429h). Mrsad Almrsad. Mtb'tAlmhmwdyh. Jdh.

5. Al'kbry, Abw Albqa'. Shrh Dywan Aby Altyb Almtnby. Dbt Wtshyh: Mstfa Alsqa - Ebrahym Alabyary'bdalhfyz Shlby, Dar Alm'rfh, Byrwt.

6. Al'qad, 'bas Mhmwd. Mtal'at Fy Alktb Walhyah. Dar Alktab Al'rby. Byrwt.

7. Al'qad, 'bas Mhmwd, Ysalwnk. T3. Dar Alktab Al'rby. Byrwt.

8. 'rb, Hsyn (1380h). Bhth Fy Alsh'r. Shyfh Alblad Als'wdyh - Al'dd 653. Jdh.

9. Abw Alanwar, Mhmd (1987). Hrkh Alsh'r Fy Al'raq. T2. Dar Alm'arf. Alqahrh.

10. Fqyhy, Ahmd 'a'l (1432h). 'bdallh 'bdaljbar Astthna'y Fy Alzmn Alghabr. Shyfh 'kaz - Al'dd 3620. Jdh.

11. Hamd, 'bdallh (1988). Nqd 'la Nqd. Mtbw'at Alnady Aladby Balqsym.

12. Hsyn, Th (1954). Altwjyh Aladby. Dar Alktab Al'rby. Byrwt.

13. Khtab, 'Ezt (1422h). Mwsw't Aladb Al'rby Als'wdy Alhdyth. Dar Almfrdat. Alryad.

14. Khldwn, Abn (2003). Mqdmt Abn Khldwn. T1. Dar Alfkr. Byrwt. 
15. Mhmwd, Zky Njyb (1982). M' Alsh'ra'. T3. Dar Alshrwq. Alqahrh.

16. Almla'kh, Nazk (1959). Dywan Shzaya Wrmad. T2. Almktb Altjary Lltba'h Waltwzy' Walnshr. Bghdad

17. Almla'kh, Nazk (1974). Qdaya Alsh'r Alm'asr. T4. Dar Al'lm Llmlayyn. Byrwt .

18. Alnwyhy, Mhmd (1971). Qdyt Alsh'r Aljdyd. T2. Dar Alfkr. Alqahrh .

19. Alqr'awy, 'bdallh (1370h). Mrsad Almnhl Tnqsh Aldqh Walnzahh. Shyft Alblad Als'wdyh - Al'dd 102. Jdh.

20. Alqyrwany, Abn Rshyq. Al'mdh Fy Mhasn Alsh'r Wadabh Wnqdh. Thqyq: Mhmd Mhyy Aldyn 'bdalhmyd. Dar Aljyl. Byrwt.

21. Rwmyh, Whb Ahmd (1996). Sh'rna Alqdym Walnqd Aljdyd. Slslt 'alm Alm'rfh. Alkwyt.

22. Alsasy, 'bdalslam (1377h). T'qyb 'la Nqd. Shyfh Alblad Als'wdyh- Al'dd 2512. Jdh.

23. Alsasy, 'bdalslam (1951). Sh'ra' Alhjaz Fy Al'sr Alhdyth. Dar Alktab Al'rby. Byrwt.

24. Alsasy, 'mr Altyb (1415h). Almwjz Fy Tarykt Aladb Al'rby Als'wdy. T2. Dar Zhran. Jdh

25. Alsban, Mhmd Srwr (1383h). Adb Alhjaz. T3. Dar Alasfhany Wshrkah. Jdh.

26. Shakr, Mhmwd Mhmd (1996). Nmt S'b Wnmt Mkhyf. T1. Mtb't Almdny. Alqahrh.

27. Alshnty, Mhmd Salh (1422h). Alnqd Aladby Alm'asr Fy Almmlkh Al'rbyh Als'wdyh- Mlamhh Watjahath Wqdayah. T1. Alandls Llnshr Waltwzy'. Ha'l.

28. Srhan Hsyn (1377h). Alams Alda". Shyfh Alblad Als'wdyh- Al'dd 2509. Jdh.

29. Altyb, 'bdallh. Almrshd Ela Fhm Ash'ar Al'rb Wsna'etha. Dar Alathar Aleslamyh. Alkwyt. 